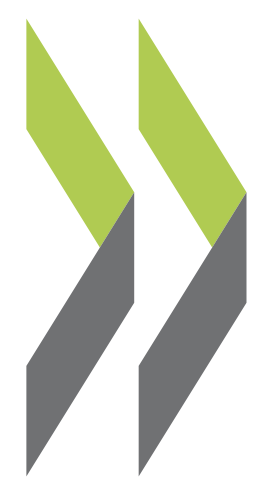

OECD Science, Technology and Industry Working Papers $2020 / 08$

\title{
Structural adjustment and changes to employment use in Japan
}

\section{Timothy DeStefano,} Filipe Silva, Sho Haneda, Hyeog Ug Kwon

https://dx.doi.org/10.1787/f58e9301-en 


\section{OECD Science, Technology and Industry Working Papers}

OECD Working Papers should not be reported as representing the official views of the OECD or of its member countries. The opinions expressed and arguments employed are those of the authors. Working Papers describe preliminary results or research in progress by the author(s) and are published to stimulate discussion on a broad range of issues on which the OECD works. Comments on Working Papers are welcomed, and may be sent to OECD Directorate for Science, Technology and Innovation, OECD, 2 rue André-Pascal, 75775 Paris Cedex 16, France; e-mail: sti.contact@oecd.org.

This document, as well as any data and map included herein, are without prejudice to the status of or sovereignty over any territory, to the delimitation of international frontiers and boundaries and to the name of any territory, city or area.

(C) OECD 2020

You can copy, download or print OECD content for your own use, and you can include excerpts from OECD publications, databases and multimedia products in your own documents, presentations, blogs, websites and teaching materials, provided that suitable acknowledgment of OECD as source and copyright owner is given. All requests for commercial use and translation rights should be submitted to rights@oecd.org. 


\section{Acknowledgements}

This paper results from joint work between the OECD Secretariat and researchers at the Nihon University, Japan. It was conducted as a part of the project "East Asian Industrial Productivity" undertaken at the Research Institute of Economy, Trade and Industry (RIETI). This paper uses micro data based on the "Census of Manufacturers (Kougyou Toukei Chousa in Japanese) which is conducted by the Ministry of Economy, Trade and Industry (METI)

The authors would like to acknowledge the voluntary contribution provided by Japan to the OECD to conduct research in the area of structural adjustment. The authors are grateful for helpful comments and suggestions by Kyoji Fukao (Hitotsubasi University), Makoto Yano (RIETI), Masayuki Morikawa (RIETI) and seminar participants at RIETI. The authors are also grateful to Chiara Criscuolo, Koen De Backer, Paolo Falco, Guy Lalanne, Carlo Menon, Nick Johnstone and Dirk Pilat for comments on the analytical framework and on earlier versions of the draft. Angela Gosmann and Márcio Carvalho provided editorial support. 


\title{
STRUCTURAL ADJUSTMENT AND CHANGES TO EMPLOYMENT USE IN JAPAN
}

\author{
Timothy DeStefano, Filipe Silva (OECD), \\ Sho Haneda (Nihon University), and
}

Hyeog Ug Kwon (Nihon University and RIETI)

This paper examines the determinants of structural adjustment in Japan and identifies several factors that explain the use of certain employment types. Its findings are based on a novel plant-level dataset that provides considerable detail on the types of employees used by Japanese manufacturers between 2001 and 2014. Analysis of this dataset shows that growth in the diffusion of robotics is linked to fewer non-regular employees, which seems to be partially driven by the positive association between robot adoption and the dismissal of certain types of non-regular workers. It also finds that offshoring from Japan to other countries contributes to the use of both regular and non-regular workers, while higher plant productivity is related to the use of more regular workers. Finally, establishments that experienced job dismissals appear to substitute non-regular workers for regular workers.

Keywords: Structural adjustment, Employment composition, Layoffs

JEL codes: J21, J23. 


\section{Table of contents}

Acknowledgements 3

$\begin{array}{ll}\text { Chapter 1. Introduction } & 7\end{array}$

Chapter 2. Background on the composition of employment in Japan 9

2.1. History of Haken law and Haken-layoffs 9

2.2. Literature on the determinants of employee use 11

2.3. Economics literature on the use of non-regular workers in Japan 11

Chapter 3. Data 13

3.1. Data description 13

3.2. Summary statistics $\quad 13$

Chapter 4. The evolution of employee composition 15

4.1. The composition of employment by year 15

4.2. Employment composition by prefecture $\quad 16$

4.3. Employment composition by sector $\quad 21$

Chapter 5. Empirical results 23

5.1. Determinants of compositional change and employee use 23

Chapter 6. Conclusion 33

$\begin{array}{ll}\text { References } & 36\end{array}$

$\begin{array}{ll}\text { Annex A. Additional tables and figures } & 39\end{array}$

\section{Tables}

Table 1. Types of employment contracts in Japan 9

$\begin{array}{lr}\text { Table 2. Changes to the Worker Dispatch Law over time } & 10\end{array}$

Table 3 Key variables and data sources $\quad 13$

Table 4 Descriptive statistics of main variables $\quad 14$

Table 5 Determinants of Employee Use $\quad 25$

Table 6 Heterogeneous effects of TFP on employee use by quartile 26

Table 7 Determinants of concentrated dismissals by employment type $\quad 28$

Table 8 Heterogeneous effects of TFP on concentrated dismissals by employment type, by TFP quartile $\quad 29$

Table 9 Effects of concentrated dismissals ( $\mathrm{t}-3, \mathrm{t}-4, \mathrm{t}-5)$ on present employee composition 31

Table 10 Impact of concentrated dismissals ( $\mathrm{t}-5)$ on present employment use 32 


\section{6 | STRUCTURAL ADJUSTMENT AND CHANGES TO EMPLOYMENT USE IN JAPAN}

Table A.1. Worker Dispatch Law: Targeted jobs

Table A.2. Sectoral classifications

Table A 3 . Determinants of Employee Use, controlling for output and wages

Table A.4. Determinants of Employee Use, lagged TFP

Table A.5. Effects of concentrated dismissals $(\mathrm{t}-1, \mathrm{t}-2, \mathrm{t}-3, \mathrm{t}-4, \mathrm{t}-5)$ on present employee composition

\section{Figures}

Figure 1 Share of employee types by year

Figure 2 Share of part-time to regular workers in Japanese Prefectures

Figure 3 Share haken to regular workers in Japanese Prefectures

Figure 4 Share of part-time and haken to regular workers in Kanto, 2014

Figure 5 Share of part-time and haken to regular workers in Kansai, 2014

Figure 6 Share of employee types by 2-digit sector, 2014

Figure 7 Share of employee types by 4-digit sector, 2014

Figure A.1. Share of employee types by 2-digit sector, 2001 


\section{Chapter 1. Introduction}

Firms in a dynamic economy are continuously under pressure to adjust and evolve (Calvino, Criscuolo and Menon, 2015 [1]; Davis and Haltiwanger, 2014 ${ }_{[2]}$ ). Economic development, changing competitive conditions across economies, innovation and the emergence of new technologies and product markets are a number of factors that compel firms to change (Baqaee and Farhi, 2020 $0_{[3]}$ ). The ability of businesses and sectors to adapt to these trends can influence their future competitive trajectory. Therefore, in order to remain economically viable, parts of the economy may, at times, need to undergo a process of structural adjustment. This process often involves adjusting the workforce to economically viable levels. It also leads to a reallocation of resources from the least productive (or shrinking) to the most productive (or expanding) areas of economic activity, which can result in significant transformations of the labour market (OECD, 2017 $[4]) .{ }^{1}$

Firms sometimes attempt to overcome these imbalances through mass layoffs. While mass layoffs affect a sizable number of workers, entailing significant human and social costs and are concentrated in time and geography, thus represent a channel of adjustment that poses particular policy challenges (Silva et al., 2019 $9_{[5]}$ ).

Another channel through which firms can adjust is by substituting regular full-time employment with temporary/part-time workers - i.e. changes in the composition of employment. Doing so can provide firms with greater flexibility and lower labour costs, by reducing expenses associated with benefits such as pensions, housing assistance, commuting costs and others (Asao, 2011 $1_{[6]}$ ), but may also have important adverse effects on workers. This type of employment substitution may take place in the event/aftermath of an economic shock and/or as a gradual structural adjustment process.

In Japan, firms tend to favour adjustment through changes in employee composition as opposed to mass layoffs, which are rare. Japan's labour market since the 1970s was characterised by long-term employment and promotion through seniority. After the macroeconomic shock of 1992, many firms found that their labour structure was no longer efficient and needed reform (Kambayashi, 2017 ${ }_{[7]}$ ). In response, several Japanese firms adjusted their employee composition away from regular full-time employees towards nonregular workers. ${ }^{2}$ The two main types of non-regular workers in Japan are those on parttime and haken contracts. ${ }^{3}$ Part-time workers tend to be hired directly by the firm while haken workers are indirectly hired through employment agencies. Non-regular workers in general are paid considerably less than regular workers and they can be dismissed much more flexibly.

Understanding the determinants of employee composition as a mechanism for structural adjustment is relevant to policymakers for a number of reasons. This mechanism may allow firms to restructure and increase competitiveness without firing workers, thereby reducing shocks to local regions. It may also enable the economy to maintain similar levels of employment while mitigating a substantial drop in consumer demand, particularly for vulnerable communities. ${ }^{4}$ While firms may temporarily rely on non-regular workers to get through economic downturns, they may begin to favour these types of workers over regular staff, for the long-run. Such shift may have important social implications, and might require considering policies towards workers that may help mitigate adverse social consequences. Moreover, this may reduce the incentive for both firms and individuals to engage into human capital accumulation. 
The objective of this paper is to assess the evolution of employment use by Japanese manufacturers and identify the main determinants of changes in employment composition as a form of structural adjustment. ${ }^{5}$ The paper starts by providing a descriptive analysis of the evolution of employment composition across years, industries and regions. Econometric techniques are then used to identify how various plant and sector characteristics are associated with the employment of certain types of workers. Since worker composition is also influenced by how employees are dismissed, the analysis also examines the relationship between plant/sector characteristics and the dismissal of different types of workers. Moreover, in an attempt to identify the potential link between concentrated dismissals and employment composition, the paper also assesses whether previous concentrated dismissals predict the current employment of certain worker types, i.e. do firms that dismissed workers in the past rely more on non-regular or regular workers today. ${ }^{6}$

The analysis finds that on the one hand exposure to automation leads to the use of a greater proportion of regular workers. This is likely driven by the fact that these technologies are linked to the dismissal of non-regular workers and the hiring of regular workers. On the other hand offshoring is correlated with a greater reliance on the share of non-regular workers. Productivity growth is associated with the use of greater numbers of both regular and non-regular workers in absolute terms. However, more productive plants rely on a greater proportion of regular workers than non-regular workers. Interestingly, those that have achieved high productivity levels (irrespective of productivity growth), hire greater numbers of non-regular workers, but are also more likely to dismiss them. Finally, the analysis finds that establishments that experienced concentrated job dismissals in the past are more likely to substitute away from regular to non-regular workers in the future. 


\title{
Chapter 2. Background on the composition of employment in Japan
}

\begin{abstract}
Mass layoffs of regular workers are quite rare in Japan because of long-term employment systems driven by employment practice (Kambayashi, 2017 $\left[7^{7}\right]$ ). In particular, the reluctance to layoff regular workers is partly explained by employers' commitment to their workers on the one hand, and by regulation that makes it difficult and costly to dismiss regular workers on the other (OECD, 2015 $\left.{ }_{[8]}\right)$. Seen in this light, it is not surprising that masslayoffs are relatively infrequent in the Japanese labour market (Sugeno and Yamakoshi, $\left.2014_{[9]}\right)$. As a consequence, Japanese firms face challenges when met with adverse economic shocks that require streamlining costs. One of the ways in which firms have sought to reduce costs is through early retirement incentives, reduced overtime, less/lower bonuses, hiring freezes, amongst other practices (Kambayashi and Kato, 2017 ${ }_{[10]}$ ). Firms have also attempted to reduce labour costs by relying more on non-regular workers. Adjustment costs involving non-regular workers can be considerably lower because contacts are more flexible and allow for rapid adjustments during economic downturn (Yokoyama, Higa and Kawaguchi, $2019_{[11]}$ ), as well as more gradual adjustments if needed both in terms of firm employment growth or reduction.

This paper relies on three main employment classifications contained in the Census of Manufacturers including, regular, part-time and haken workers. These employment types differ in terms of their type of contract and who is employing them (see Table 1). ${ }^{7}$ In terms of employment type, regular worker contracts are tenured, while that of part-time and "haken" workers are non-tenured. ${ }^{8}$ As for employment relationships, regular and part-time workers are directly hired by the company where they work at, while haken workers, on the other hand are indirectly employed, through a third party employment agency (Takahashi, 2012 [12] $)$. The Census of Manufacturers contains another type of worker, called temporary workers, whose contracts are less than one month. It is however not possible to distinguish whether these are haken or part-time workers, thus the paper excludes temporary workers from the analysis. ${ }^{9}$
\end{abstract}

Table 1. Types of employment contracts in Japan

\begin{tabular}{|c|c|c|c|c|}
\hline Availability & Employee type & Contract type & Employer relationship & Included in analysis? \\
\hline Yes & Regular & Tenured & \multirow{2}{*}{ Direct employment } & Yes \\
\hline Yes & Part-time $^{10}$ & \multirow{2}{*}{$\begin{array}{c}\text { Non-tenured } \\
\text { (>1 month) }\end{array}$} & & Yes \\
\hline Yes & Haken & & Indirect employment & Yes \\
\hline \multirow{2}{*}{ Only totals } & Temporary part-time workers & Non-tenured (<1 month) & Direct or indirect employment & \multirow{2}{*}{$\begin{array}{c}\text { Cannot distinguish } \\
\text { part-time from haken } \\
\text { workers }\end{array}$} \\
\hline & Temporary haken workers & Non-tenured (<1 month) & Indirect employment & \\
\hline
\end{tabular}

Source: Census of Manufacturers, calculations by authors.

\subsection{History of Haken law and Haken-layoffs}

One of the most flexible forms of employment types in Japan are haken workers. Unlike most contractual arrangements in Japan, haken workers sign an employment contract with a third party dispatch company, which provides labour to firms. The expansion of this type of contracts was facilitated by The Ordinance for Enforcement of the Act for Securing the Proper Operation of Worker Dispatching Undertakings and Improved Working Conditions for Dispatched Workers (hereinafter Worker Dispatch Law) published in 1985 and enacted in 1986. The law allowed labour supply businesses (hereafter "haken companies") to sign an employment contract with haken workers and dispatch them to other firms. At this time, 
these were in effect only for 16 specialised jobs (see Table A.1 in annex). Moreover, the contract length was limited to one year.

In 1996, 10 new jobs were added (totalling 26 jobs, the 16 jobs added in 1986 and the 10 jobs added in 1996) ${ }^{11}$. Three years later in 1999, the Haken law was emended to encompass all jobs with the exception of specific jobs (such as manufacturing positions and a few other expectations specified in Table A.1 in the annex) and the length of contracts changed to three years for original 26 jobs (specified by 1996) and one year for new jobs included in 1999. In 2004, the law encompassed manufacturing workers with contract length of one years for these jobs while the contract length for the 26 jobs specified in 1999 was removed. From 2007 contract lengths for manufacturing jobs were extended from one year to three years. ${ }^{12}$

The impact of the 2008 financial crisis heightened the public discussion about the economic and social implications of non-regular and haken contracts, particularly since these types of workers were considerably affected during the economic downturn. Since firms are required to either directly hire haken workers as a regular worker or dismiss them after a set number of years (during this period the time requirement was three years), many firms decided to let these workers go. These events were labelled "haken-layoffs". The total number of workers involved in the haken-layoff over the period of 2008-2009 was around 244000 people while the layoff of regular workers was around 50000 (Ministry of Health , Labour and Welfare, $2009_{[13]}$ ). Many haken workers not only lost employment, but also lost their homes. A number of initiatives to help these workers emerged at the time. For example, in order to help around 500 people, labour unions and Non-Profit Organisations (NPOs) organised a camp in Hibiya Park in Tokyo to provide food services and bedding (Kojima, 2010[14]).

After the haken-layoffs, the Worker Dispatch Law was amended in 2012 to help support haken workers. The new law provided a number of provisions aimed at mitigating the adverse social consequences of the use of haken employment, more specifically: prohibition of daily haken workers (this refers to workers hired for only one day at a time); disclosure on the rate of margin for haken companies; ${ }^{13}$ improvement of working conditions of haken workers, including advance notice about wages, business operations and the haken contract. The most recent amended Worker Dispatch Law published in 2015 aims to improve equality between haken workers and other types of workers, for instance, by making compulsory the provision of education and training in the work place to haken workers (Kambayashi, 2017 $[7])$. Table 2 lists the main amendments to the relevant law.

Table 2. Changes to the Worker Dispatch Law over time

\begin{tabular}{|l|l|l|}
\hline Milestones & Year & Main changes \\
\hline Publication & 1985 & \\
\hline Enactment & 1986 & \\
\hline Revision & 1996 & 10 new jobs were added. \\
\hline Revision & 1999 & Almost all jobs were included with exceptions \\
\hline Revision & 2004 & Manufacturing jobs were included \\
\hline Revision & 2007 & The length of contract was extended from one to three years for manufacturing jobs. \\
\hline Revision & 2012 & New conditions were added to mitigating the adverse social consequences for haken workers. \\
\hline Revision & 2015 & $\begin{array}{l}\text { New conditions were added to improve equality between haken and other types of workers } \\
\text { and contract lengths were limited to three years for all specified jobs }\end{array}$ \\
\hline
\end{tabular}

Source: Kambayashi (2017[7]). 


\subsection{Literature on the determinants of employee use}

Technological change is perceived to influence employment choices, the recent diffusion of industrial robotics is no different (Acemoglu and Restrepo, 2017 $[15]$; Ford, 2016 ${ }_{[16]}$; Brynjolfsson and Mcafee, 2014 $\left.{ }_{[17]}\right)$. In theory, robots and automation may take on many types of tasks and may not be restricted to only lower skilled jobs. For example, work by Frey and Osborne $\left(2017_{[18]}\right)$ suggests that roughly $47 \%$ of US employment is susceptible to automation and computerisation and that that both skilled and unskilled jobs are vulnerable to robots. Jobs most susceptible to being replaced by robots were found to be those composed of tasks that require repetitive and rudimentary activities, ranging from lower paying jobs like bicycle repairpersons and shoe mending operators to higher income jobs like real-estate brokers and accountants. ${ }^{14}$ Examining the impact of industrial robotics, Acemoglu and Restrepo $\left(2017_{[15]}\right)$ find that the adverse effects of these machines on wages and demand are more pronounced in blue-collar jobs and for workers with education below the college level. ${ }^{15}$ This paper contributes to this body of work by focusing on the impact of industrial robotics on the use of regular and non-regular workers.

The extent to which firms are exposed to global competitive pressures may also determine how they use and dismiss workers. In particular, offshoring from developed economies is found to influence the demand of skilled workers more than unskilled employees. In addition, the evidence is quite consistent across countries. See for example Feenstra and Hanson $\left(1999_{[19]}\right)$ for the US, Falk and Koebel $\left(2002_{[20]}\right)$ for Germany, Baldwin et al. $\left(2013_{[21]}\right)$ for France and Hijzen et al. $\left(2005_{[22]}\right)$ for the UK. Similarly, for Japan Kiyota and Maruyama (2017 $\left.{ }_{[23]}\right)$ and Ahn, et al (2008[24]), find evidence that offshoring from Japan is linked to an increased demand in skilled workers for manufacturing plants. The available data is described in Section 3, but does not allow to distinguish between skilled and unskilled workers, however there may be important insights regarding the effects of offshoring on regular versus non-regular employees.

Another determinant of the choice between regular and non-regular workers is how productive firms are. While not directly linked to the demand for regular and non-regular workers, recent empirical research finds a strong relationship between productivity and wages, which may suggest a positive correlation with the demand for regular workers. ${ }^{16}$ Recent OECD research using aggregated micro data across 17 countries finds a close link between productivity and wages (Berlingieri, Calligaris and Criscuolo, 2018[25]). Using micro data in Sweden, Carlsson et al $\left(2016_{[26]}\right)$ find that firms that obtain productivity shocks pay incumbent employees' higher wages. The extent to which productivity explains the composition of employment could differ depending on where in the productivity distribution the plant resides. For example, large incumbents with high efficiency irrespective of productivity growth may favour more non-regular workers to remain competitive and as a cost buffer in the event of an economic shock. This paper attempts to test this hypothesis by also estimating the importance of a plant's position along the productivity distribution for employee composition.

\subsection{Economics literature on the use of non-regular workers in Japan}

A number of papers have assessed the use of employment types in Japan. Such studies have typically focused on three main areas: i) the rise of non-regular workers in Japan, ii) the effects of employment use on firms' performance and iii) the impact of exogenous shocks on the structure and demand for regular and non-regular workers.

While non-regular contracts can allow firms to adjust more flexible to economic shocks, increased reliance on non-regular workers may lead to polarisation in tasks and wage. 
Kambayashi $\left(2017_{[7]}\right)$ explores the polarisation and replacement of regular by non-regular workers, using data from the Employment Status Survey (see Section 3. on data). This research shows that the number of non-regular workers in high-, middle- and low-income level jobs grew between 1982 and 2012, whereas the number of regular workers with middle-wage jobs decreased in 2002-2012. ${ }^{17}$ The analysis also suggests an increase in polarisation of income levels for both regular and non-regular workers, with results indicating that the number of high- and low-income jobs increased at the expenses of middle income jobs. Other papers find that the rise in the number of non-regular workers is associated with the decline in long-term employment (Asano, Ito and Kawaguchi, $2013_{[27]}$; Kawaguchi and Ueno, 2013 [28]). In terms of firm performance and employee use, Matsuura et al. (2011 $1_{[29]}$ )presents a theoretical framework, which suggests that trade liberalisation induces firms to reduce the number of goods they sell, thereby increasing the demand for non-regular since they involve lower dismissal costs. They also find that new entrants in exporting markets achieve higher growth in the number of employees, as well as a higher share of non-regular workers, when compared to non-exporters in manufacturing sectors in Japan. Similarly, Tanaka et al. (2019[30])conduct empirical analyses to quantify the impact of exogenous shocks on structural adjustment of Japanese manufacturers. They find that the external shock caused by restrictions on Japanese products in foreign jurisdiction negatively impacted the number of temporary workers due to the decrease in Japanese firms' exports. Examining the impact of exogenous shocks on the demand for workers, Yokoyama et al. $\left(2019_{[11]}\right)$ assesses the effect of changes in exchange rates on the composition of regular and non-regular employees. They show that the employment of non-regular workers was negatively affected by the appreciation of Japanese Yen. This suggests that non-regular workers might be more at risk of being dismissed when firms face negative shocks to adjust their production costs. We examine this point further, by assessing the impact of offshoring from Japan on plant employment. 


\section{Chapter 3. Data}

\subsection{Data description}

The analysis conducted in the context of this paper relies on information from three different datasets. The main data comes from the Census of Manufacturers ${ }^{18}$. This dataset contains plant level information on manufacturing firms from 2001 to $2014 .{ }^{19}$ The Census surveys two types of plants, those with less than 30 employees and those with more than 30 , where the latter type contains more information about each entity. For the purpose of this paper, we focus on the analysis on plants with more than 30 employees since the smaller class plants lack consistent information on employee types and variables needed to calculate TFP. The dataset is rich as it provides detailed information on each plant, including financials, employment, location, sector, amongst others. Importantly, the dataset contains detailed information on the types of employment contracts within each plant. Twodigit sector level variables measuring offshoring are also used in the analysis, as well as a variable that measures the diffusion of industrial robot stock. ${ }^{2021}$ The offshoring measure is constructed from the OECD Trade and Value Added dataset (TIVA) and the robot stock is estimated with data from the International Federation of Robotics (IFR).

\section{Table 3 Key variables and data sources}

\begin{tabular}{|c|c|c|c|}
\hline Variable & Short description & Source & Variation \\
\hline composition & Share of non-regular workers over regular workers within the plant & \multirow{8}{*}{$\mathrm{CM}$} & \multirow{7}{*}{ plant-time } \\
\hline regular & Headcount of the number of regular workers within the plant & & \\
\hline non-regular & Headcount of the number of non-regular workers (part-time+haken) within the plant & & \\
\hline part-time & Headcount of the number of part-time workers within the plant & & \\
\hline haken & Headcount of the number of haken workers within the plant & & \\
\hline $\begin{array}{l}\text { concentrated } \\
\text { dismissal }\end{array}$ & $\begin{array}{l}\text { If experienced considerable net employment reduction within a year i.e. a reduction of } 10 \% \text { or more } \\
(\{0 ; 1\} \text { dummy) }\end{array}$ & & \\
\hline productivity & Total factor productivity, estimated by Levinson-Petrin (2003) & & \\
\hline multi & Whether the plant is connected to a multi-plant firm ( $\{0 ; 1\}$ dummy) & & \multirow{3}{*}{$\begin{array}{l}\text { sector- } \\
\text { time }\end{array}$} \\
\hline offshoring & $\begin{array}{l}\text { Share of imported intermediate inputs (less energy) over total demand of intermediate inputs (less } \\
\text { energy) }\end{array}$ & TIVA & \\
\hline robot stock & Stock of industrial robotics, estimated with PIM assuming $10 \%$ annual depreciation & IFR & \\
\hline
\end{tabular}

Note: CM refers to the Census of Manufacturers, TIVA to OECD-WTO Trade in Value Added dataset, IFR to the International Federation of Robotics.

\subsection{Summary statistics}

Table 4 presents summary statistics of the main variables used in the analysis. Overall, the types of plants in our sample are medium to large with an average total employment of 117 persons and a median number of workers of $64 .{ }^{22}$ Japanese manufacturing plants tend to employ more regular workers than non-regular workers. ${ }^{23}$ For example, plants on average employ 86 regular and 30 non-regular workers, of which 20.2 are part-time and 9.1 are haken employees. The average share of non-regular to regular employees is around $25 \%$. The database also includes the value of revenue and its mean and median are 4858 million JP yen and 1071 million JP yen. In terms of robotic diffusion, the mean stock of industrial robotics by 2-digit sector is 22174 machines - this large number is not surprising given 
that Japan is the largest user of these machines (in terms of absolute numbers) in the world (IFR, 2017 [31]). In terms of offshoring, roughly $9 \%$ of total demanded inputs are imported, which is a relatively lower number when compared to other developed economies (OECD, $\left.2019_{[32]}\right)$. Moreover, roughly $23 \%$ of plants over the sample period experienced a concentrated dismissal, i.e. a reduction of total employment by $10 \%$ or more. ${ }^{24}$

Table 4 Descriptive statistics of main variables

\begin{tabular}{lccccc}
\hline Variable & Mean & Median & SD & $1 \%$ & $99 \%$ \\
\hline Revenue & 130,817 & 45,972 & 634,759 & $-16,967$ & $1,523,140$ \\
TFP & 5,984 & 2,917 & 8,960 & 338 & 49,356 \\
Employment & 117 & 64 & 218 & 30 & 864 \\
Regular Employment & 87 & 46 & 188 & 4 & 700 \\
Non-regular Employment & 31 & 12 & 69 & 0 & 305 \\
Part-time Employment & 20 & 7 & 46 & 0 & 218 \\
Haken Employment & 9 & 0 & 37 & 0 & 140 \\
Employee Composition & 0.96 & 0.22 & 4.26 & 0 & 12.00 \\
Plants facing concentrated dismissals & 0.23 & - & - & - & - \\
Offshoring & 0.09 & 0.08 & 0.03 & 0.04 & 0.19 \\
Robot stock & $22,174.07$ & $12,570.96$ & $30,727.07$ & 68.09 & $125,385.20$ \\
\hline
\end{tabular}

Note: All variables are levels with the except of employee composition and offshoring, which reflects the share of non-regular to regular employees in levels and the share of imported intermediate inputs (less energy) over total intermediate inputs (less energy), respectively. 


\section{Chapter 4. The evolution of employee composition}

\subsection{The composition of employment by year}

Figure 1 illustrates the proportion of employee types (regular, part-time and haken) across plants by year. Regular workers account for the lion's share, but data suggest that plants overall have been shifting away from regular to non-regular workers, although the trend is quite gradual from $78.60 \%$ of all the workers having regular employment contracts in 2001 to $71.71 \%$ in 2014 . Over the period of analysis $(2001-2014)$, the proportion of part-time and haken workers increased from $15.77 \%$ to 19.57 and $5.62 \%$ to $8.71 \%$, respectively. Marked declines in the proportion of haken workers are observed in the years corresponding to the recent financial crisis (from $12.54 \%$ in 2007 to $7.78 \%$ in 2009) consistent with the literature discussed above. The recession however appears to have had less of an impact on part-time employees, which may be due to the fact that haken employees can be dismissed easier than other types of labour and because the Worker Dispatch Law required firms to either hire them as regular employees or dismiss them.

Figure 1 Share of employee types by year

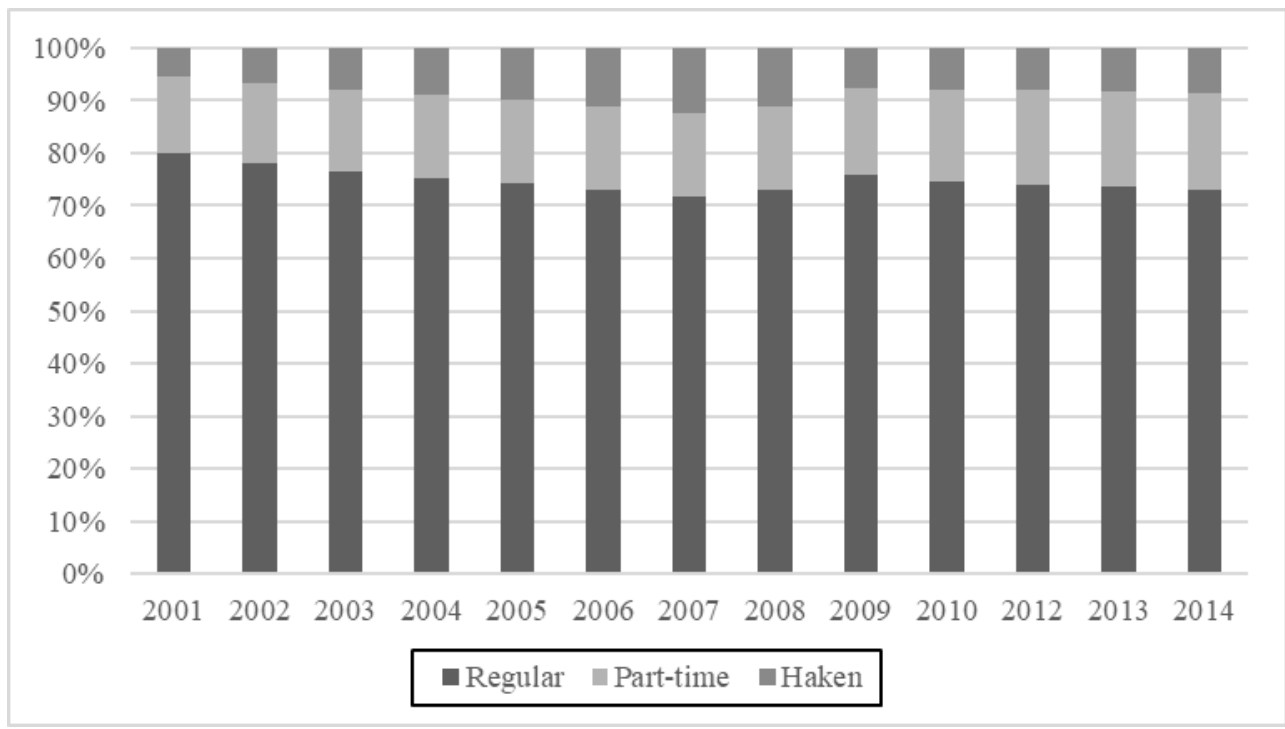

Note: The following figure illustrates the shares of employee type by year. Considering the concern of Great East Japan earthquake on official statistics, we do not use the Economic Census for Business Activity 2011. Source: Census of Manufacturers, calculations by authors. 


\subsection{Employment composition by prefecture}

While the use of part-time and haken workers has increased overtime, Figure 2 and Figure 3 show that this has been experienced across most of Japanese prefectures. Nevertheless, certain prefectures appear to use part-time and haken employees more intensively than others. Prefectures in the Kanto and Kansai as well as Kinki use these types of employees more intensively than say in the Tohoku and Shikoku prefectures. Hokkaido appears to be an early and intensive user of part-time workers and more so than other prefectures in Japan. This may not be surprising given the high presence of food processing and fishing sectors in this prefecture (Hokkaido, 2009 ${ }_{[29]}$ ). Therefore it is important to note that some of the determinants explaining regional concentration of employment are due to spatial factors but may also be industrial composition and firm characteristics (Silva et al., 2019 ${ }_{[3]}$ ).

Disaggregating geographic employee composition further, Figure 4 and Figure 5 illustrate the share of part-time to regular and haken to regular workers at the municipality level for Kanto and Kansai prefectures. The reason for focusing on these prefectures is because they host the largest population in the country and thus cover a large variety of industries. ${ }^{25} \mathrm{In}$ terms of part-time workers, Hayama-machi and Oiso-machi, and Higashiyoshino-mura and Nose-cho municipalities have the highest intensity of part-time workers in the Kanto and Kansai. As for haken employees, Ranzan-machi and Tamamura-machi, and Kusatsu-shi and Osaka-shi, Konohana-ku have the highest intensity of haken workers.

Despite these differences in the share of non-regular employees highlighted in this section, little is known about the underlying reasons explaining the variation among prefectures of employment use overtime. Better understanding the drivers of geographical differences is beyond the scope of this paper, but future work in this area could provide important policy insights. 
Figure 2 Share of part-time to regular workers in Japanese Prefectures

2001
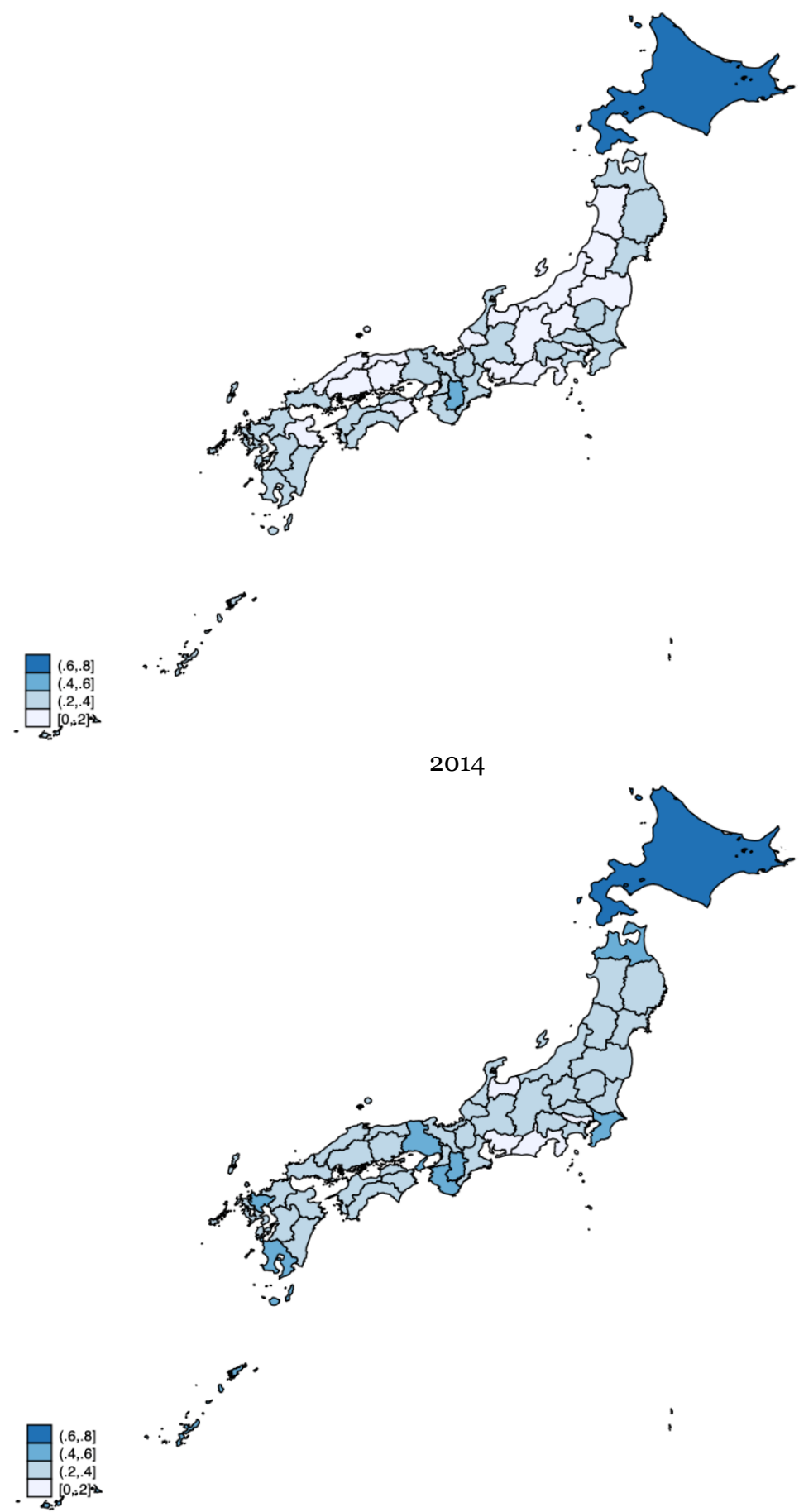

Note: This figure illustrates the share of part-time to regular employees by prefecture, 2001 and 2014. The share of non-regular workers ranges from zero ( 0 , white) to all $(1$, dark shaded). Prefectures filled with darker shades indicate a higher share of non-regular workers in that Prefecture.

Source: Census of Manufacturers, calculations by authors. 3 
Figure 3 Share haken to regular workers in Japanese Prefectures

2001

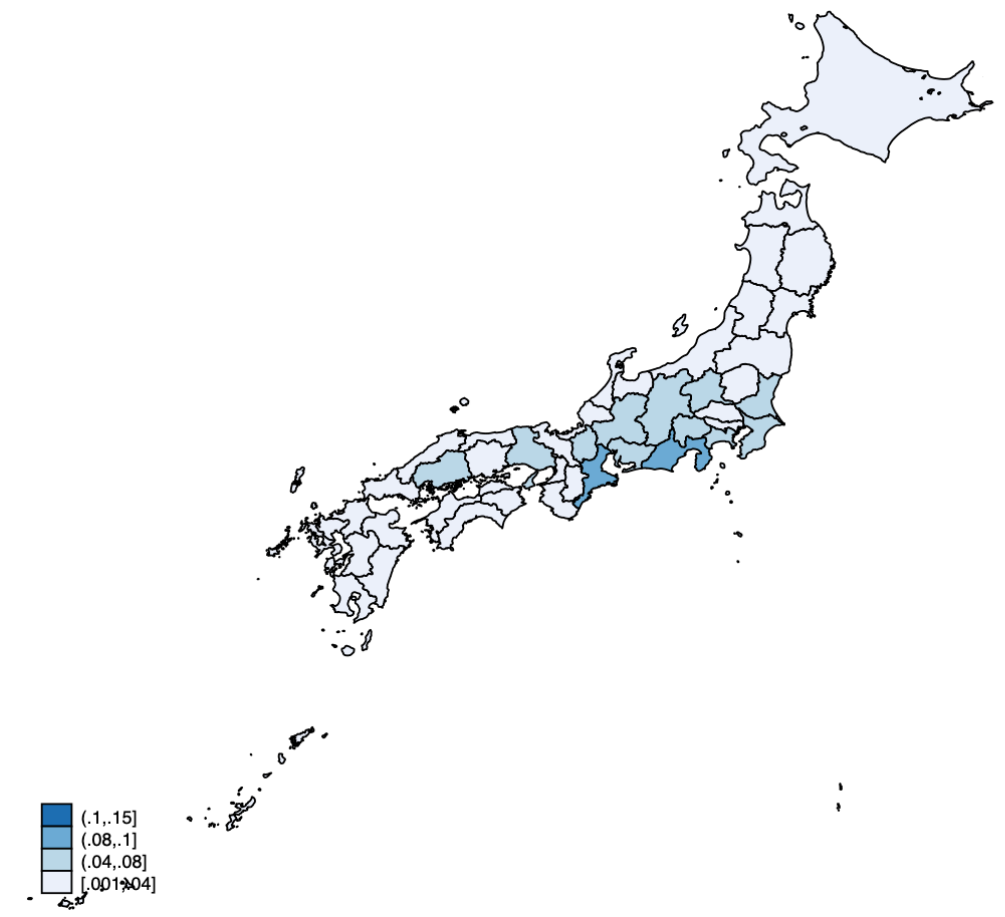

2014
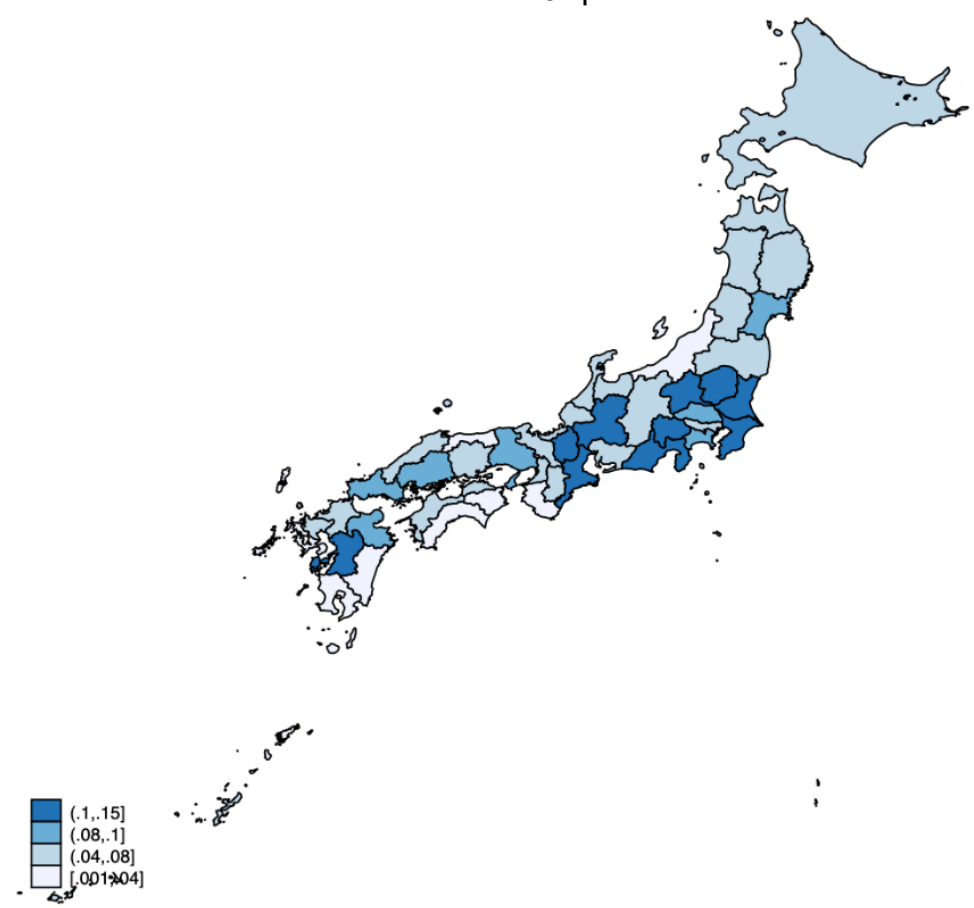

Note: This figure illustrates the share of haken to regular employees by prefecture, 2001 and 2014 . The share of haken workers ranges from close to zero $(0.01$, white) to all (1, dark shaded). Prefectures filled with darker shades indicate a higher share of haken workers in that Prefecture.

Source: Census of Manufacturers, calculations by authors. 
Figure 4 Share of part-time and haken to regular workers in Kanto, 2014

Share of Part-time to Regular Workers

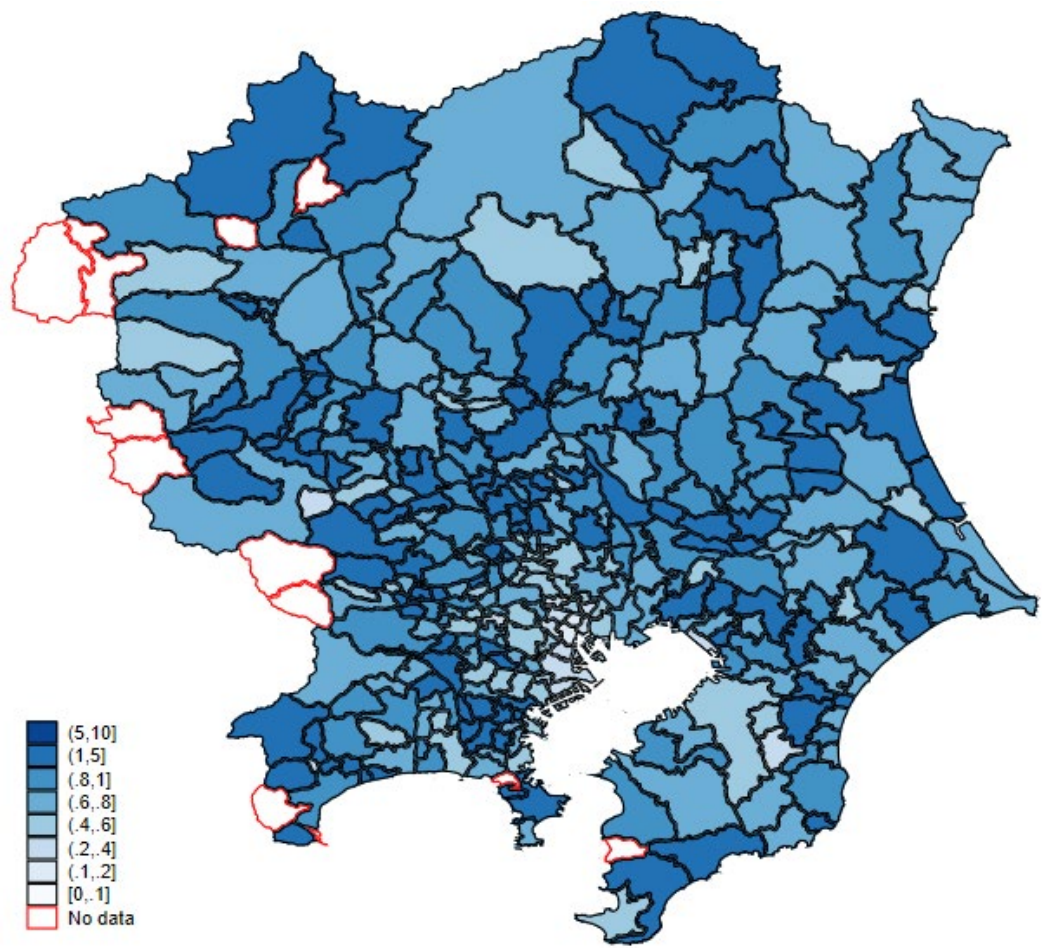

Share of Haken to Regular Workers

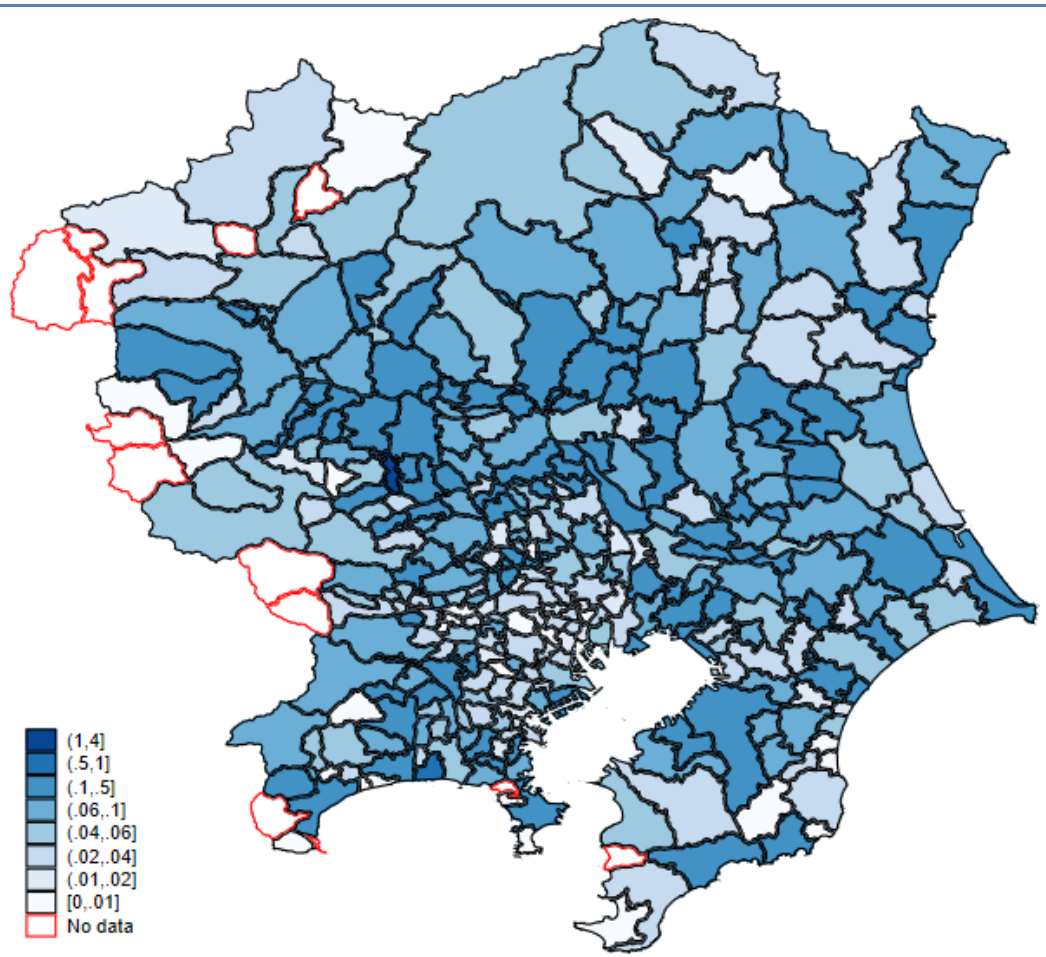

Note: This figure illustrates the share of part-time and haken to regular employees in the Kanto prefecture, 2014. The share of non-regular workers ranges from zero ( 0 , white) to all $(1$, dark shaded). Prefectures filled with darker shades indicate a higher share of non-regular workers in that prefecture.

Source: Census of Manufacturers, calculations by authors. 
Figure 5 Share of part-time and haken to regular workers in Kansai, 2014 Share of Part-time to Regular Workers

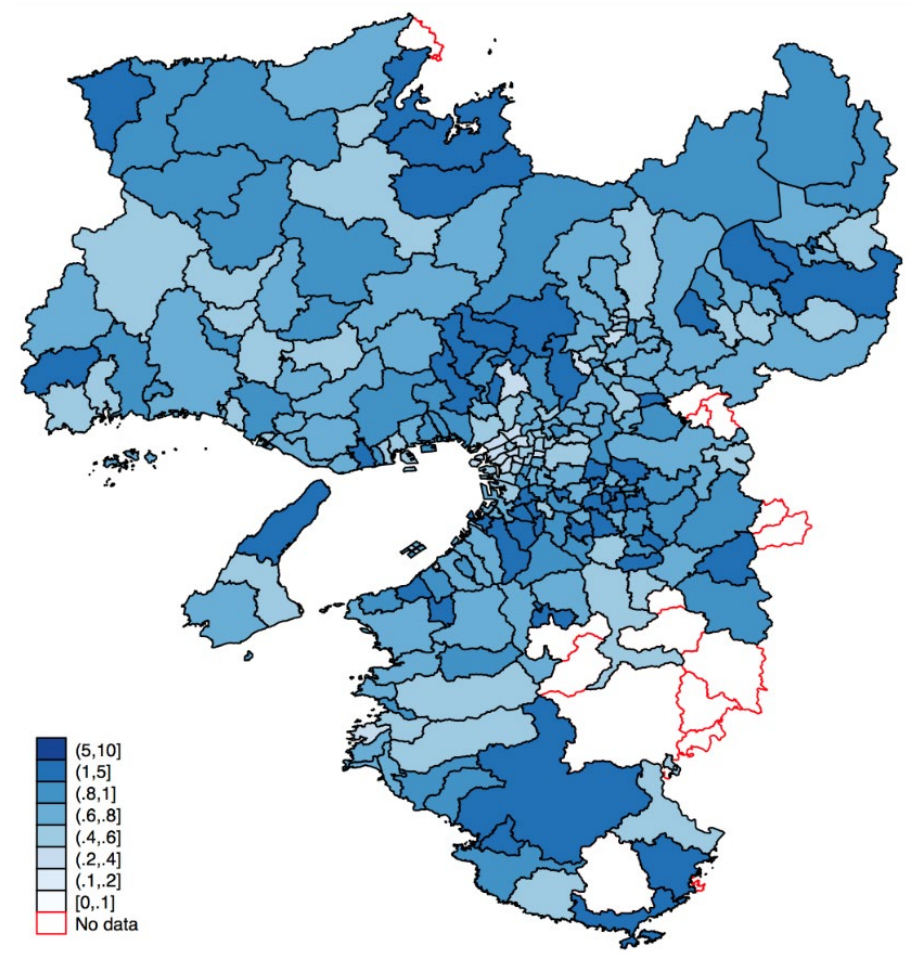

Share of Haken to Regular Workers

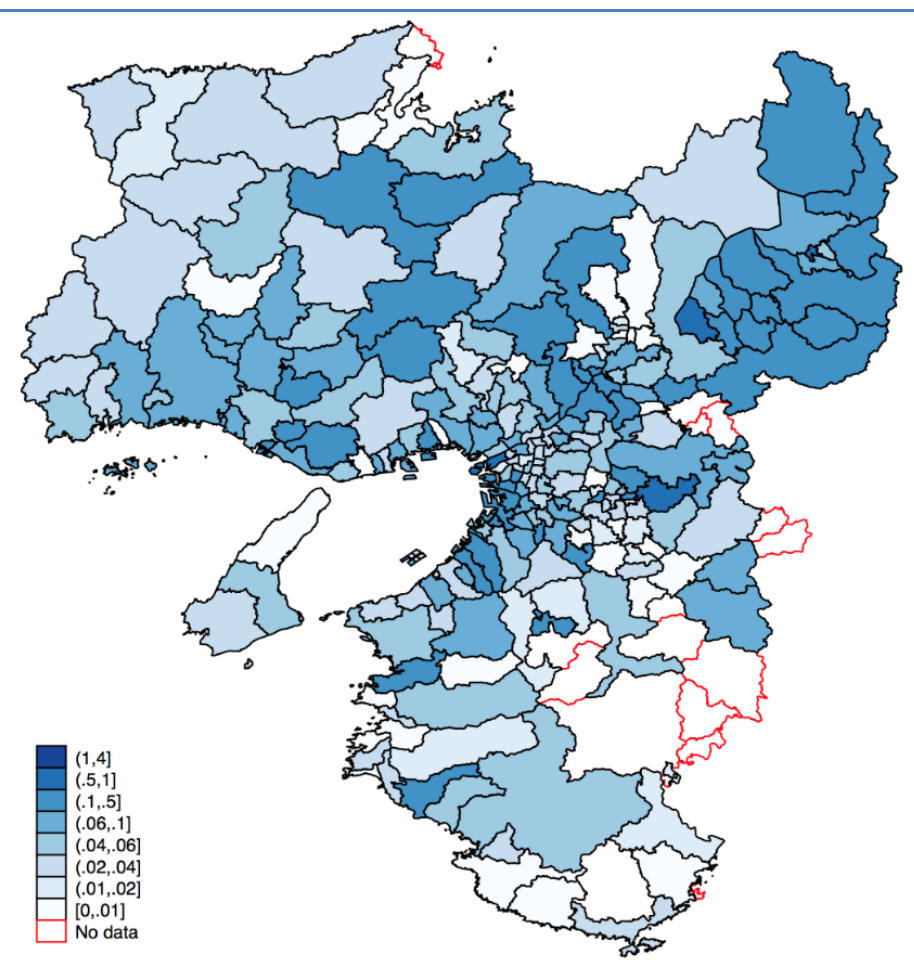

Note: This figure illustrates the share of part-time and haken to regular employees in the Kansai prefecture, 2014. The share of haken workers ranges from zero ( 0 , white) to all $(1$, dark shaded). Prefectures filled with darker shades indicate a higher share of haken workers in that prefecture.

Source: Census of Manufacturers, calculations by authors. 


\subsection{Employment composition by sector}

The employee composition across industries is considerably heterogeneous (see Figure 6). For some industries such as Food Manufacturing (classification 9), for the average firm roughly $60 \%$ of their employment were part-time and haken workers in 2014 . At the same time, for the average plant in Plastics and Non-Ferrous Metals industries, (classification 18 and 23 , respectively), more than $90 \%$ of their employees are regular workers. Moreover, the proportion of employee types across industries has not been constant overtime (see Figure A.1 in the appendix for the distribution in 2001). Figure 7 below further explores the heterogeneity in employment types across 4-digit sector level. Disaggregating the statistics demonstrates even greater differences in employment composition across narrowly defined sectors. For example, in the Cotton Spinning sector, roughly $80 \%$ of the workforce are part-time and haken, while in the Medical instruments and Apparatus sector almost all employees are regular workers. The data thus far demonstrate the need for micro data (to control for the host of unobservable characteristics) in order to have a detailed understanding of the determinants of employee composition while at the same time allowing for an examination of heterogeneity across plant characteristics, i.e. a strong motivation for using plant-level data.

Figure 6 Share of employee types by 2-digit sector, 2014

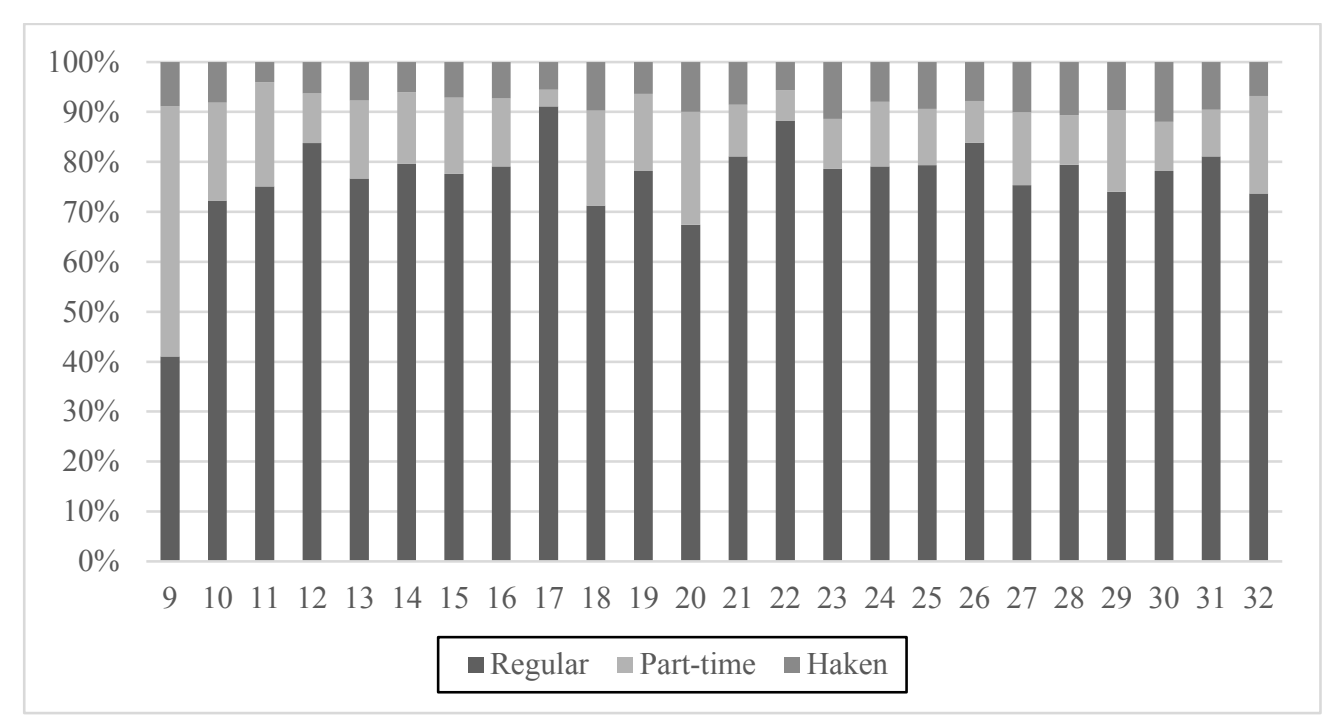

Note: The following figure illustrates the shares of employee type by 2-digit sector for the year 2014. Sector classifications are the Japanese Standard Industrial Classification.

Source: Census of Manufacturers, calculations by authors. 
22 I STRUCTURAL ADJUSTMENT AND CHANGES TO EMPLOYMENT USE IN JAPAN

Figure 7 Share of employee types by 4-digit sector, 2014

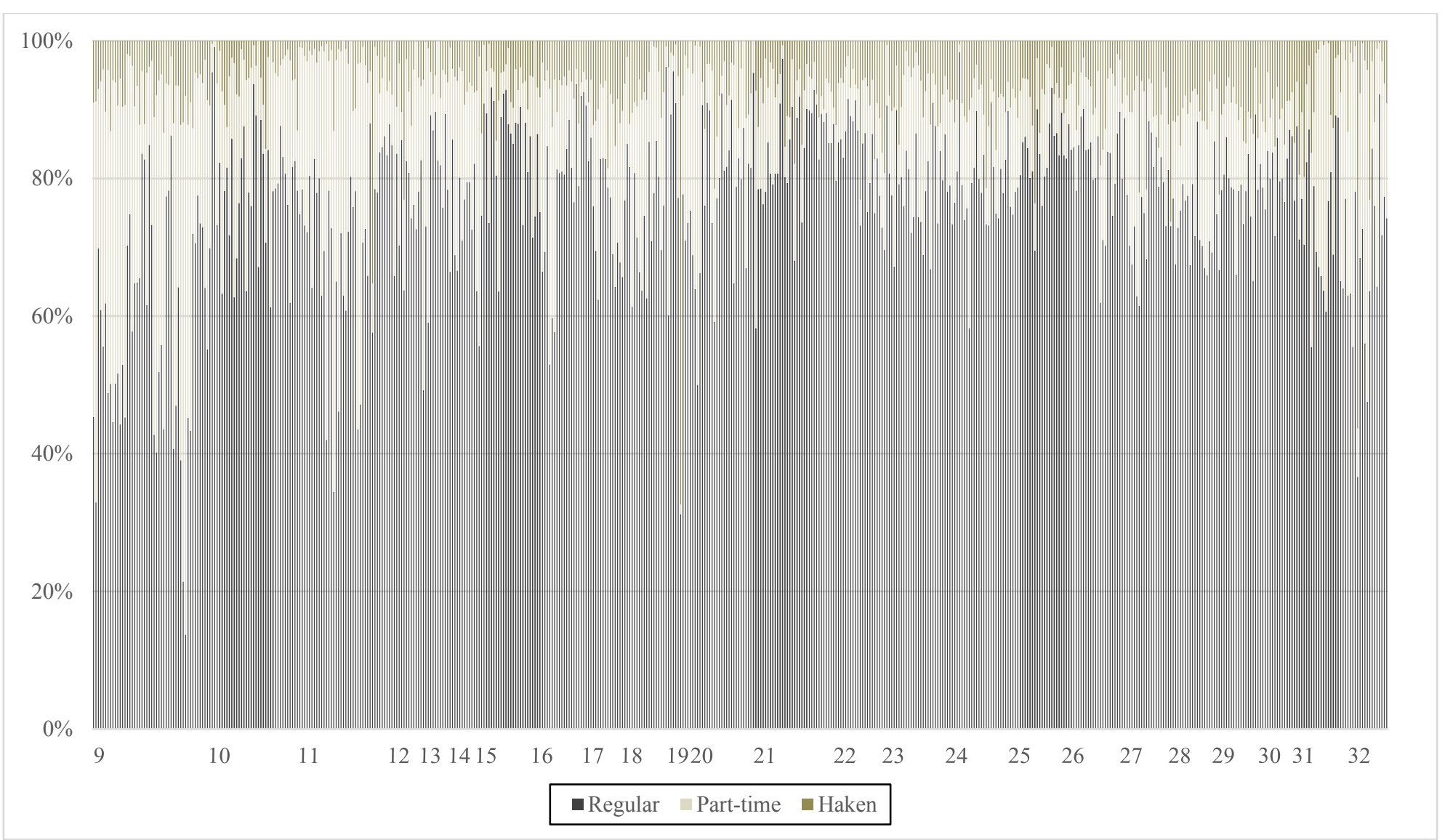

Note: The following figure illustrates in the share of employee type by 4-digit sector for the year 2014. Sector classifications are the Japanese Standard Industrial Classification.

Source: Census of Manufacturers, calculations by authors. 


\section{Chapter 5. Empirical results}

\subsection{Determinants of compositional change and employee use}

The following section summarises the results from a number of empirical exercises undertaken to understand the nature and determinants of employee composition in Japan. The first part of this analysis assesses plant and sectoral determinants of employee use, including the share of non-regular to regular workers on the one hand and the numbers of regular, non-regular, part-time and haken workers on the other hand. Another factor that may influence the types of employees used within the firm, are the types of employees that are dismissed over time. Although mass layoffs are uncommon in Japan, concentrated dismissals do occur, therefore the second sub-section assess how various firm and sector characteristics determine the dismissal of certain types of workers. The final section explores whether instances of plant concentrated dismissals in the past influence the types of workers used in the present. Firms, for example, may use concentrated dismissals as an opportunity to adjust composition of the labour they hire. The final section examines the extent to which instances of concentrated dismissals in the past result in greater reliance of non-regular workers in the present.

\subsubsection{Predictors of compositional change and employee use}

The first section assess how various plant and sector characteristics determine the use of employment types within the plant. Our measure of employee composition - similar to Matsuura et al $\left(2011_{[29]}\right)$ - is the share of non-regular employees over regular employees at establishment $i$ in sector $s$ at time $t$, illustrated in Equation 1 below. ${ }^{26}$ Composition is one of the five key dependent variables. Other dependent variables include the number of regular, non-regular, part-time and haken workers. All dependent variables are denoted by $y_{i s t}$ and shown in Equation 2 below. These are regressed separately on firm productivity

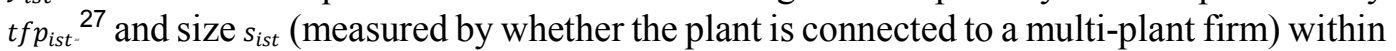
an OLS framework. The framework also includes two sector controls, offshoring ${ }^{28}$ and robot stock ${ }^{29}$ signified by $\delta_{s t}$. A host of other factors are also controlled for in the model (signified by $\chi_{i t}$ ),comprising year, city, 4-digit sector and plant fixed effects. The inclusion of year and plant fixed effects means that the regressions are capturing within firm changes overtime.

Another interesting and relevant question, particularly to policy makers relates to the decision regarding types of employment that plants make at different locations along the productivity distribution. For example, plants which increase productivity year on year, may favour greater numbers of all types of workers due to their growth needs. Those at the top or bottom quartile of the productivity distribution may however require considerably different employment types. In order to assess this, the analysis builds off Equation 2 including TFP along with TFP interacted with dummy variables indicating a plants' quartile position within the productivity distribution at the start of the sample period, the year 2001 (See Equation 3). Since the purpose here is to assess differences in employment needs across different productivity levels rather than changes, plant fixed effects are excluded. 


$$
\begin{aligned}
& \operatorname{comp}_{\text {ist }}=\frac{{\text { ıvıl } \text { reg }_{\text {ist }}}_{\text {reg }}}{\text { ist }} \\
& y_{i s t}=\alpha_{0}+\alpha_{1} t f p_{i s t}+\alpha_{2} s_{i s t}+\alpha_{3} \delta_{s t}+\alpha_{4} \chi_{i s t}+\varepsilon_{i t} \\
& \begin{array}{r}
y_{i t}=\alpha_{0}+\alpha_{1} t f p_{i s t}+\alpha_{2} t f p_{i s t} * q 1+\alpha_{3} t f p_{i s t} * q 2+\alpha_{4} t f p_{i s t} \\
* q 3+\alpha_{5} t f p_{i s t} * q 4+\alpha_{6} s_{i s t}+\alpha_{7} \delta_{s t}+\alpha_{8} \chi_{i s t}
\end{array} \\
& +\varepsilon_{i t}
\end{aligned}
$$

\section{Empirical results}

The results presented in Table 5 examine the links between changes in plant and sector characteristics on changes in employment use. Productivity is positively associated with greater use of regular workers instead of non-regular workers, as indicated by the negative coefficient of the composition variable. At the same time, more productive plants employee greater numbers of all employee types, including non-regular, part-time and haken workers. This is not surprising given that productivity is positively correlated with firm size which is well documented in the literature Melitz, 2003; Bartelsman et al., 2013 (Bartelsman, Haltiwanger and Scarpetta, 2013 $[34]$; Lucas, 1978 ${ }_{[35]}$; Melitz, 2003 $\left.{ }_{[36]}\right){ }^{30}$ This is also somewhat consistent with our size measure i.e. those connected to a multi-plant firm, for regular and non-regular workers. ${ }^{31}$ It is important to note that the weak effect found for the multi-plant variable may be driven partially by the inclusion of plant fixed effects, which washes out the predictive power from variables, which tend to be time invariant.

The diffusion of industrial robotics is correlated with an increase in the use of regular workers and a decline in the numbers of non-regular and part-time workers. The mechanism for why this is occurring is not entirely clear. One explanation may be that plants are using robots to carry out tasks that were traditionally done by non-regular workers. To explore this further, the section below will examine the extent to which robotics are linked with the dismissal of non-regular and regular workers. ${ }^{32}$

Somewhat surprising, offshoring is positively correlated with greater numbers of all types of employees (i.e. regular, non-regular, part-time and haken workers). One explanation may be that offshoring allows firms to concentrate on their key strengths, by outsourcing lower value marginal activities, thereby enhancing the overall performance and scale of the firm. An alternative explanation may simply be that firms that are becoming larger are more likely to outsource than smaller firms. In terms of employee composition, the offshoring coefficient is negative however the relationship is not statistically significant. Much of the literature on offshoring and labour demand focuses on skills while here we are examining regular vs non-regular employment. ${ }^{33}$ In fact, when one considers the list of jobs that can be undertaken say by haken workers (stipulated by the Worker Dispatch Law) many of these are positions require employees that are medium to highly skilled. On the one hand, the results are somewhat similar to Matsuura et al $\left(2011_{[29]}\right)$, which find that trade liberalization induces firms to reduce the number of goods they sell, thereby increasing the demand for non-regular workers since they involve lower dismissal costs. On the other hand, we cannot confirm from these results whether firms are substituting away from regular to non-regular workers as a result of changes in offshoring and/or competition from abroad given the lack of statistical significance with composition. 
Table 5 Determinants of Employee Use

\begin{tabular}{|c|c|c|c|c|c|}
\hline Dependent variable & Composition & Regular & Non-Reg & Part-time & Haken \\
\hline \multirow[t]{2}{*}{ TFP } & $-0.020^{* * *}$ & $0.204^{* * *}$ & $0.150^{* * *}$ & $0.111^{* * *}$ & $0.134^{* * *}$ \\
\hline & $(0.00)$ & $(0.00)$ & $(0.00)$ & $(0.00)$ & $(0.00)$ \\
\hline \multirow[t]{2}{*}{ Multi-plant } & 0.000 & $0.014^{* * *}$ & $0.013^{* *}$ & 0.006 & 0.009 \\
\hline & $(0.00)$ & (0.00) & $(0.00)$ & (0.00) & (0.00) \\
\hline \multirow[t]{2}{*}{ Offshoring } & -0.001 & $0.078^{* * *}$ & $0.145^{* * *}$ & $0.151^{* * *}$ & $0.168^{* * *}$ \\
\hline & $(0.00)$ & $(0.00)$ & $(0.01)$ & $(0.01)$ & $(0.02)$ \\
\hline \multirow[t]{2}{*}{ Robot stock } & $-0.020^{* * *}$ & $0.052^{* * *}$ & $-0.053^{* *}$ & $-0.056^{* * *}$ & 0.011 \\
\hline & (o.00) & $(0.00)$ & (o.00) & $(0.00)$ & $(0.00)$ \\
\hline \multicolumn{6}{|l|}{ Fixed effects } \\
\hline Plant & $\checkmark$ & $\checkmark$ & $\checkmark$ & $\checkmark$ & $\checkmark$ \\
\hline Year & $\checkmark$ & $\checkmark$ & $\checkmark$ & $\checkmark$ & $\checkmark$ \\
\hline 4 digit sector & $\checkmark$ & $\checkmark$ & $\checkmark$ & $\checkmark$ & $\checkmark$ \\
\hline Region & $\checkmark$ & $\checkmark$ & $\checkmark$ & $\checkmark$ & $\checkmark$ \\
\hline Observations & 506501 & 507666 & 507666 & 507666 & 507666 \\
\hline R-squared & 0.895 & 0.937 & 0.817 & 0.834 & 0.701 \\
\hline
\end{tabular}

Note: Composition refers to the share or non-regular to regular workers. Regular, non-regular, part-time and haken represent the number of employee types by plant. Fixed effects included in each model listed in the table. Regressions are clustered at the plant-year level with robust standard errors in parenthesis. Level of significance are $* * * 1 \%, * * 5 \%, * 10 \%$.

While TFP is found to be linked to the composition of employment across plants, there may be heterogeneous effects depending on where a plant stands within the productivity distribution. In order to assess this, we interact TFP with dummy variables, which corresponds to the productivity quartiles of the TFP distribution where the plant resides (at the start of the sample period 2001). The non-interacted term reflects the effects of TFP for plants in the bottom quartile, and each interacted term shows the additional effect (over the bottom quartile) for each of these higher quartiles. ${ }^{34}$

Similar to the previous results, TFP is negatively correlated with employee composition, however we find that those located at the top productivity quartile use significantly less non-regular workers than plants on lower rungs of the productivity distribution (see Table 6). This is consistent with the result found for the number of regular employees used, i.e. plants at the top quartile use more regular workers than those at the bottom quartile. The results for non-regular workers are more nuanced and somewhat polarising. For example, plants located at the bottom and top quartiles are found to use greater numbers of part-time workers, while plants on the second quartile seem to use less part-time workers. With regards to haken workers, plants at the bottom quartile use the most while those located above the bottom quartile use less. Taken together the results suggest that the levels of TFP matter for the types of labour employed, where the most productive plants appear to use a greater proportion of regular workers than non-regular staff. ${ }^{35}$ 
Table 6 Heterogeneous effects of TFP on employee use by quartile

\begin{tabular}{|c|c|c|c|c|c|}
\hline Dependent variable & Composition & Regular & Non-Reg & Part-time & Haken \\
\hline \multirow[t]{2}{*}{ TFP $<25^{\text {th }}$ percentile } & $-0.066^{* * * *}$ & $0.465^{* * *}$ & $0.264^{* * *}$ & $0.008^{* * *}$ & $0.441^{* * * *}$ \\
\hline & (0.00) & (o.0o) & (o.0o) & (o.oo) & (o.0o) \\
\hline \multirow[t]{2}{*}{$\begin{array}{l}\text { TFP } 25 \text { th-5oth } \\
\text { percentile }\end{array}$} & $-0.015^{* * *}$ & $0.012^{* * *}$ & $-0.027^{* * *}$ & $-0.007^{* * *}$ & $-0.028^{* * *}$ \\
\hline & (0.00) & (0.00) & (0.00) & (0.00) & $(0.00)$ \\
\hline \multirow[t]{2}{*}{$\begin{array}{l}\text { TFP }{ }^{*} \text { 5th-75th } \\
\text { percentile }\end{array}$} & $-0.012^{* * *}$ & $0.020^{* * *}$ & $-0.012^{* * *}$ & $0.008^{* * *}$ & $-0.022^{* * *}$ \\
\hline & (0.00) & (0.00) & (0.00) & $(0.00)$ & $(0.00)$ \\
\hline \multirow[t]{2}{*}{$\begin{array}{l}\text { TFP } 75 \text { th-10oth } \\
\text { percentile }\end{array}$} & $-0.008^{* * *}$ & $0.047^{* * *}$ & $0.011^{* * *}$ & $0.024^{* * *}$ & $-0.008^{* * *}$ \\
\hline & $(0.00)$ & $(0.00)$ & $(0.00)$ & $(0.00)$ & $(0.00)$ \\
\hline \multirow[t]{2}{*}{ Multi-plant } & $0.049^{* * *}$ & $-0.016^{* * *}$ & $0.062^{* * *}$ & $0.052^{* * *}$ & $0.006^{* *}$ \\
\hline & $(0.00)$ & $(0.00)$ & $(0.00)$ & $(0.00)$ & $(0.00)$ \\
\hline \multirow[t]{2}{*}{ Offshoring } & 0.008 & -0.007 & $0.102^{* * *}$ & $0.160^{* * *}$ & $0.116^{* * * *}$ \\
\hline & $(0.00)$ & (o.01) & $(0.02)$ & $(0.02)$ & $(0.02)$ \\
\hline \multirow[t]{2}{*}{ Robot stock } & $-0.043^{* * *}$ & $0.041^{* * *}$ & $-0.123^{* * *}$ & $-0.140^{* * *}$ & 0.016 \\
\hline & (0.00) & (0.00) & (0.01) & (0.01) & (0.01) \\
\hline \multicolumn{6}{|l|}{ Fixed effects } \\
\hline Year & $\checkmark$ & $\checkmark$ & $\checkmark$ & $\checkmark$ & $\checkmark$ \\
\hline 4 digit sector & $\checkmark$ & $\checkmark$ & $\checkmark$ & $\checkmark$ & $\checkmark$ \\
\hline Region & $\checkmark$ & $\checkmark$ & $\checkmark$ & $\checkmark$ & $\checkmark$ \\
\hline Observations & 514727 & 515876 & 515876 & 515876 & 515876 \\
\hline R-squared & 0.331 & 0.529 & 0.262 & 0.257 & 0.198 \\
\hline
\end{tabular}

Note: Composition refers to the share or non-regular to regular workers. Regular, non-regular, part-time and haken represent the number of employee types by plant. Fixed effects included in each model are listed in the table. Regressions are clustered at the plant-year level with robust standard errors in parenthesis. Level of significance are $* * * 1 \%, * * 5 \%, * 10 \%$.

\subsubsection{Determinants of employee dismissals}

Another factor which may influence changes in employee composition relates to the types of workers that firms choose to dismiss. In order to shed light on this relationship, the following section assesses the link between firm characteristics and the types of employee dismissals. One way to approach this question empirically would be to simply look at changes in employment of a plant year on year. However, differences may not actually reflect dismissals but rather lags between hiring or relocating employees to different plants within the firm. In order to capture considerable changes in employment (which is less likely to be result of hiring lags), a concentrated dismissal is classified to have occurred if the employment of the plant decreased by $10 \%$ or more (see Equation 4$).{ }^{36}$ Moreover, the data captures net changes in employment instead of gross job destruction, but this is an unavoidable caveat with this type of databases. There are however many advantages of using plant-level data, including the fact that it allows capturing reallocation across different plants within a firm. 


$$
\begin{array}{r}
\text { ConDis }_{\text {ist }}=1 \text { if } \operatorname{semp}_{\text {it }} \leq-10 \% \\
\text { ConDis }_{\text {ist }}=0 \text { if } \Delta e m p_{i t}>-10 \%
\end{array}
$$

The empirical model used to estimate the determinants of concentrated dismissals of manufacturing plants in Japan is illustrated in Equation 5. ConDis $s_{i s t}$ is a dummy variable reflecting whether a plant experienced a decline (of $10 \%$ or more) in total employment, between time t- 1 to t. The same plant $\left(t f p_{i s t} \& s_{i s t}\right)$ and sector $\left(\delta_{s t}\right)$ determinants used in Equation 2 are included along with plant, year, region and sector fixed effects. Moreover, in order to assess whether there is heterogeneity in the effects of TFP on dismissals at different productivity quartiles, we augment the model including the TFP-quartile interaction terms (see Equation 6) and excluding plant fixed effects as we are interested in assessing the importance of TFP levels, in line with the approach described in the preceding section.

$$
\begin{aligned}
& \text { ConDis }_{i s t}=\alpha_{0}+\alpha_{1} t f p_{i s t}+\alpha_{2} s_{i s t}+\alpha_{3} \delta_{s t}+\alpha_{4} \chi_{i s t}+\varepsilon_{i t} \\
& \begin{array}{c}
\text { ConDis }_{i s t}=\alpha_{0}+\alpha_{1} t f p_{i s t}+\alpha_{2} t f p_{i s t} * q 1+\alpha_{3} t f p_{i s t} * q 2 \\
+\alpha_{4} t f p_{i s t} * q 3+\alpha_{5} t f p_{i s t} * q 4+\alpha_{6} s_{i s t}
\end{array} \\
& \begin{array}{l}
+\alpha_{4} t f p_{i s t}^{*} q 3+\alpha_{5} t \\
+\alpha_{7} \delta_{s t}+\alpha_{8} \chi_{i s t}+\varepsilon_{i t}
\end{array}
\end{aligned}
$$

\section{Empirical results}

The results in Table 7 illustrate the link between plant and sector characteristics on the concentrated dismissals of all types of workers, regular, part-time and haken employees. TFP is negatively correlated with the dismissal of any types of workers. One potential explanation for this may be that more productive plants tend employ their factors of production more efficiently and therefore may be less adversely impacted by shocks. Robotics diffusion is negatively related to the dismissal of regular workers but positively linked to the concentrated dismissals non-regular work types. These results are consistent with what was found previously - growth in robot diffusion is linked with fewer nonregular and more regular workers (See Table 5). Taking these two results together suggest that industrial robotics may be used in place of certain types of non-regular workers. Interestingly, plants residing in sectors more exposed to offshoring are less likely to resort to concentrated dismissal either in terms of regular or any non-regular types of employment. Interestingly, the results for multi-plant firms indicate that multi-plant firms are less prone to concentrated dismissals, notably when it comes to regular workers negative coefficient for the concentrated dismissals of regular workers. This could suggest that plants connected to multi-plant firms are able to reallocate workers across the different plants and production units when faced with structural adjustment pressures, thus avoiding layoffs. Reallocation within large business groups in Japan has in some instances helped avoid mass layoffs - see for example the restructuring of the Japanese steel sector in the 1970s (OECD, 2015 $\left.{ }_{[8]}\right)$ or the more recent adjustment in the electronics industry (Cabinet Office, $\left.2013_{[37]}\right){ }^{37}$ 
Table 7 Determinants of concentrated dismissals by employment type

\begin{tabular}{|c|c|c|c|c|c|}
\hline Dependent variable & All workers & Regular & Non-Reg & Part-time & Haken \\
\hline \multirow[t]{2}{*}{ TFP } & $-0.212^{* * *}$ & $-0.212^{* * *}$ & $-0.081^{* * *}$ & $-0.064^{* * *}$ & $-0.036^{* * *}$ \\
\hline & (0.00) & $(0.00)$ & (0.00) & (0.00) & (0.00) \\
\hline \multirow[t]{2}{*}{ Multi-plant } & $-0.018^{* * *}$ & $-0.017^{* * *}$ & -0.003 & -0.000 & 0.003 \\
\hline & (0.00) & (0.00) & (0.00) & (0.00) & (0.00) \\
\hline \multirow[t]{2}{*}{ Offshoring } & $-0.125^{* * *}$ & $-0.112^{* * *}$ & $-0.041^{* * *}$ & $-0.035^{* * *}$ & $-0.027^{* * *}$ \\
\hline & $(0.01)$ & $(0.01)$ & $(0.01)$ & (o.01) & $(0.00)$ \\
\hline \multirow[t]{2}{*}{ Robot stock } & $-0.047^{* * *}$ & $-0.067^{* * *}$ & $0.026^{* * *}$ & $0.030^{* * *}$ & -0.002 \\
\hline & $(0.00)$ & (0.00) & (o.0o) & (o.0o) & (o.0o) \\
\hline \multicolumn{6}{|l|}{ Fixed effects } \\
\hline Plant & $\checkmark$ & $\checkmark$ & $\checkmark$ & $\checkmark$ & $\checkmark$ \\
\hline Year & $\checkmark$ & $\checkmark$ & $\checkmark$ & $\checkmark$ & $\checkmark$ \\
\hline 4 digit sector & $\checkmark$ & $\checkmark$ & $\checkmark$ & $\checkmark$ & $\checkmark$ \\
\hline Region & $\checkmark$ & $\checkmark$ & $\checkmark$ & $\checkmark$ & $\checkmark$ \\
\hline Observations & 507666 & 507666 & 507666 & 507666 & 507666 \\
\hline R-squared & 0.141 & 0.138 & 0.115 & 0.127 & 0.223 \\
\hline
\end{tabular}

Note: Concentrated dismissals refer to decline of the workforce by $10 \%$ or more at an individual plant within one year. Fixed effects included in each model are stated in the table. Regressions are clustered at the plantyear level with robust standard errors in parenthesis. Level of significance are $* * * 1 \%, * * 5 \%, * 10 \%$.

The relationship between TFP and concentrated dismissals by employee types appears to be heterogeneous depending on the position plants along the productivity distribution. Interestingly, plants at the top of the productivity distribution are more likely to dismiss all types of workers (both regular and non-regular), when compared to plants located on lower rungs of the productivity distribution. At the same time, TFP is still negatively correlated with dismissals for all employees and regular workers with coefficients of -0.010 and 0.022 , respectively. ${ }^{38}$

When considering heterogeneous effects for non-regular worker types, the results indicate that plants at the top of the TFP distribution are the most likely to dismiss non-regular types of employees. This is the case for both part-time and haken workers. However the size of the effects is markedly larger for the dismissal of haken workers than for part-time. Taken together, the results in both Table 6 and Table 8 suggest that the most productive plants may use certain types of non-regular workers as a flexible form of labour to adjust to structural economic changes. 
Table 8 Heterogeneous effects of TFP on concentrated dismissals by employment type, by TFP quartile

\begin{tabular}{|c|c|c|c|c|c|}
\hline Dependent variable & All workers & Regular & Non-Reg & Part-time & Haken \\
\hline \multirow[t]{2}{*}{ TFP $<25^{\text {th }}$ percentile } & $-0.029^{* * *}$ & $-0.038^{* * *}$ & -0.001 & $-0.009^{* * *}$ & $0.037^{* * *}$ \\
\hline & (o.0o) & (o.00) & (0.00) & (o.0o) & (o.0o) \\
\hline \multirow[t]{2}{*}{$\begin{array}{l}\text { TFP* } 25 \text { th-5oth } \\
\text { percentile }\end{array}$} & $0.004^{* * *}$ & $0.003^{* * *}$ & $0.003^{* * *}$ & $0.004^{* * *}$ & $0.000^{* *}$ \\
\hline & (o.0o) & (o.0o) & (o.0o) & (o.0o) & (o.0o) \\
\hline \multirow[t]{2}{*}{$\begin{array}{l}\text { TFP }{ }^{*} \text { 5oth- } 75^{\text {th }} \\
\text { percentile }\end{array}$} & $0.006^{* * *}$ & $0.005^{* * *}$ & $0.005^{* * *}$ & $0.005^{* * *}$ & $0.003^{* * *}$ \\
\hline & (0.00) & (0.00) & (0.00) & (0.00) & (0.00) \\
\hline \multirow[t]{2}{*}{$\begin{array}{l}\text { TFP }{ }^{*} 75 \text { th-10oth } \\
\text { percentile }\end{array}$} & $0.009^{* * *}$ & $0.008^{* * *}$ & $0.006^{* * *}$ & $0.005^{* * *}$ & $0.004^{* * *}$ \\
\hline & (o.00) & (0.00) & (0.00) & (o.0o) & (o.0o) \\
\hline \multirow[t]{2}{*}{ Multi-plant } & $0.019^{* * *}$ & $0.017^{* * *}$ & O.000 & -0.000 & $0.003^{* * *}$ \\
\hline & (o.0o) & (o.0o) & (o.00) & (o.oo) & (o.00) \\
\hline \multirow[t]{2}{*}{ Offshoring } & $-0.136^{* * *}$ & $-0.121^{* * *}$ & $-0.057^{* * *}$ & $-0.048^{* * *}$ & $-0.041^{* * *}$ \\
\hline & (0.00) & (0.00) & (o.01) & (o.01) & (0.00) \\
\hline \multirow[t]{2}{*}{ Robot stock } & $-0.043^{* * *}$ & $-0.059^{* * *}$ & 0.006 & 0.008* & -0.003 \\
\hline & (0.00) & (o.00) & (0.00) & (0.00) & (0.00) \\
\hline \multicolumn{6}{|l|}{ Fixed effects } \\
\hline Year & $\checkmark$ & $\checkmark$ & $\checkmark$ & $\checkmark$ & $\checkmark$ \\
\hline 4 digit sector & $\checkmark$ & $\checkmark$ & $\checkmark$ & $\checkmark$ & $\checkmark$ \\
\hline Region & $\checkmark$ & $\checkmark$ & $\checkmark$ & $\checkmark$ & $\checkmark$ \\
\hline Observations & 515876 & 515876 & 515876 & 515876 & 515876 \\
\hline R-squared & 0.013 & 0.012 & 0.012 & 0.008 & 0.043 \\
\hline
\end{tabular}

Note: Concentrated dismissals refer to decline of the workforce by $10 \%$ or more at an individual plant within one year. Fixed effects included in each model are stated in the table. Regressions are clustered at the plantyear level with robust standard errors in parenthesis. Level of significance are $* * * 1 \%, * * 5 \%, * 10 \%$.

\subsubsection{Concentrated dismissals as a mechanism for adjusting employee composition}

Another important question relating to structural adjustment is how firms reorganise themselves after downsizing. In particular, what types of employees do firms use after experiencing concentrated dismissals? Firms that need to reduce costs by dismissing workers may prefer more flexible forms of employment, such as part-time and haken workers in the future. This may be particularly true given the cost of dismissing regular workers in Japan as discussed previously. This section therefore examines the extent to which concentrated dismissals in the past influence the use of different types of employment in the present.

The estimation method uses a standard OLS framework illustrated in Equation (7), where $y_{i s t}$ represents the various employment measures, including composition on one hand, and numbers of regular, non-regular, part-time and haken workers on the other hand. The explanatory variable of interest ConDis $_{i s t-3,4,5}$ is a dummy variable reflecting whether a plant experienced a decline (of $10 \%$ or more) in total employment at time $t-3, t-4, t-$ 5. The rationale for starting with $t-3$ and ending with $t-5$ is to ensure that the lag is far enough in the past that the relationship is not endogenous to decisions made in the present and not too distant from the present that it lacks predictive power. ${ }^{39}$ The model includes 
the same plant and sector level controls) along with the same fixed effects used in Equations 2 and 5.

$$
y_{i s t}=\alpha_{0}+\alpha_{1} \text { ConDis }_{i s t-5}+\alpha_{2} \chi_{i s t}+\alpha_{3} \delta_{s t}+\varepsilon_{i t}
$$

\section{Empirical results}

Table 9 presents the econometric results of a regression exploring the relationship between concentrated dismissals and the contemporaneous share of non-regular to regular workers. The results suggest that plants which experienced a concentrated dismissal in 3 to 5 years in the past, use more non-regular to regular workers today. These results are consistent regardless of whether the lagged effects of dismissal are estimated separately or all included within the same regression. Moreover albeit somewhat weaker, the effects of concentrated dismissal in time t-1 and $\mathrm{t}-2$ are positive and statistically significant with employee composition (see Table A.5 in the Appendix). Moreover, the relationships are robust to different concentrated dismissal definitions, such as declines of employment by $5 \%$ to $20 \%$ and for longer lagged period. ${ }^{40}$

These results are consistent to what is found when we look at the numbers of employee types used in the present after a concentrated dismissal in the past. Specifically, plants, which experienced concentrated dismissals in t-5 in the past employ fewer regular workers and more non-regular, part-time, and haken workers in the present (See Table 10). ${ }^{41} \mathrm{In}$ addition, the magnitude of the effect of the concentrated dismissal appears to have the largest positive effect on haken use. ${ }^{42}$ These results suggest that plants which experienced downsizing in the past, tend to favour a more low cost and flexible workforce instead of full-time regular workers. 
Table 9 Effects of concentrated dismissals (t-3, t-4, t-5) on present employee composition

\begin{tabular}{|c|c|c|c|c|}
\hline Dependent variable & Composition & Composition & Composition & Composition \\
\hline \multirow[t]{2}{*}{ Conc. dismissals, t-3 } & $0.010^{* *}$ & & & $0.009^{* *}$ \\
\hline & (0.00) & & & (o.00) \\
\hline \multirow[t]{2}{*}{ Conc. dismissals, t-4 } & & $0.012^{* * *}$ & & O.011** \\
\hline & & (0.00) & & (0.00) \\
\hline \multirow[t]{2}{*}{ Conc. dismissals, t- 5} & & & $0.012^{* * *}$ & $0.012^{* *}$ \\
\hline & & & (0.00) & (0.00) \\
\hline \multirow[t]{2}{*}{ TFP } & $-0.008^{* * *}$ & $-0.005^{* * *}$ & -0.002 & O.000 \\
\hline & (0.00) & (0.00) & (0.00) & (0.00) \\
\hline \multirow[t]{2}{*}{ Multi-plant } & 0.001 & 0.001 & -0.000 & 0.001 \\
\hline & (0.00) & (0.00) & (0.00) & (0.00) \\
\hline \multirow[t]{2}{*}{ Offshoring } & $-0.016^{* * *}$ & $-0.015^{* * *}$ & -0.006 & -0.000 \\
\hline & (o.0o) & (0.00) & (0.00) & (0.00) \\
\hline \multirow[t]{2}{*}{ Robot stock } & $-0.022^{* * *}$ & $-0.015^{* * *}$ & $-0.013^{* * *}$ & $-0.033^{* *}$ \\
\hline & (o.00) & (o.00) & (0.00) & (0.00) \\
\hline \multicolumn{5}{|l|}{ Fixed effects } \\
\hline Plant & $\checkmark$ & $\checkmark$ & $\checkmark$ & $\checkmark$ \\
\hline Year & $\checkmark$ & $\checkmark$ & $\checkmark$ & $\checkmark$ \\
\hline 4 digit sector & $\checkmark$ & $\checkmark$ & $\checkmark$ & $\checkmark$ \\
\hline Region & $\checkmark$ & $\checkmark$ & $\checkmark$ & $\checkmark$ \\
\hline Observations & 295044 & 286730 & 247484 & 196,056 \\
\hline R-squared & 0.917 & 0.919 & 0.923 & 0.928 \\
\hline
\end{tabular}

Note: Composition refers to the share or non-regular to regular workers. Concentrated dismissal refers to a reduction of total employment of the plant of $10 \%$ or more in year $t-3, t-4$ and $t-5$. Fixed effects included in each model are stated in the table. Regressions are clustered at the plant-year level with robust standard errors in parenthesis. Level of significance are ${ }^{* * *} 1 \%,{ }^{* *} 5 \%,{ }^{*} 10 \%$. 
Table 10 Impact of concentrated dismissals (t-5) on present employment use

\begin{tabular}{|c|c|c|c|c|}
\hline Dependent variable & Regular & Non-Reg & Part-time & Haken \\
\hline \multirow[t]{2}{*}{ Conc. dismissals, t-5 } & $-0.011^{* *}$ & $0.043^{* * *}$ & $0.017^{* * *}$ & $0.050^{* * *}$ \\
\hline & (0.00) & (0.00) & (0.00) & (0.00) \\
\hline \multirow[t]{2}{*}{ TFP } & $0.148^{* * *}$ & $0.169^{* * *}$ & $0.131^{* * *}$ & $0.15^{* * * *}$ \\
\hline & (o.0o) & (0.00) & (0.00) & (o.0o) \\
\hline \multirow[t]{2}{*}{ Multi-plant } & $0.010^{* * *}$ & $0.014^{*}$ & $0.024^{* * *}$ & 0.012 \\
\hline & (o.0o) & (0.00) & (0.00) & (0.00) \\
\hline \multirow[t]{2}{*}{ Offshoring } & 0.013 & $0.088^{* * *}$ & $0.099^{* * *}$ & $0.096^{* * *}$ \\
\hline & (o.0o) & (o.00) & (0.00) & (o.00) \\
\hline \multirow[t]{2}{*}{ Robot stock } & $0.024^{* * *}$ & $-0.073^{* * *}$ & $-0.025^{*}$ & $-0.071^{* * *}$ \\
\hline & (0.00) & (o.01) & (0.01) & (0.01) \\
\hline \multicolumn{5}{|l|}{ Fixed effects } \\
\hline Plant & $\checkmark$ & $\checkmark$ & $\checkmark$ & $\checkmark$ \\
\hline Year & $\checkmark$ & $\checkmark$ & $\checkmark$ & $\checkmark$ \\
\hline 4 digit sector & $\checkmark$ & $\checkmark$ & $\checkmark$ & $\checkmark$ \\
\hline Region & $\checkmark$ & $\checkmark$ & $\checkmark$ & $\checkmark$ \\
\hline Observations & 247899 & 247899 & 247899 & 247899 \\
\hline R-squared & 0.958 & 0.857 & 0.869 & 0.756 \\
\hline
\end{tabular}

Note: Composition refers to the share or non-regular to regular workers. Regular, non-regular, part-time and haken represent the number of employee types by plant. concentrated dismissal refers to a reduction of total employment of the plant for $10 \%$ or more between time $t-5$. Fixed effects included in each model are stated in the table. Regressions are clustered at the plant-year level with robust standard errors in parenthesis. Level of significance are ${ }^{* * *} 1 \%,{ }^{* *} 5 \%,{ }^{*} 10 \%$. 


\section{Chapter 6. Conclusion}

Firms in a dynamic market are continuously under pressure to adjust and evolve over time. The ability of firms to adapt to these competitive and technological factors can influence their growth trajectory. One of the ways in which firms have attempted to overcome these imbalances is through mass layoffs (Silva et al., 2019 ${ }_{[5]}$ ). Another mechanism that a business can use to adjust is by substituting away from regular full-time employment to non-regular workers. Doing so may allow businesses to become more flexible and reduce labour costs (Asao, 2011 $1_{[6]}$ ). Both methods can result in adverse effects to labour market participants.

The objective of this paper is to assess the evolution of employment composition for Japanese manufacturers and identify the main determinants of this style of structural change. Descriptive statistics show that plants are using greater proportions of non-regular workers to regular workers across regions, sectors and time. At the same time, the use of employee type is considerably heterogeneous across narrowly defined sectors and more so for individual production units.

The econometric evidence identifies a number of factors that influence the use of employment types. In terms of technology change, growth in the diffusion of robotics is linked to the employment of fewer non-regular employees. This appears to be partially driven by the fact that robots are also related to the dismissal of certain types of non-regular workers. Offshoring to Japan leads to the use of a higher proportion of non-regular to regular workers, potentially due to increased competition faced by plants from abroad.

Plant productivity is also an important determinant for the types of employees used. Increases in plant productivity is associated with greater numbers of regular and nonregular workers in absolute numbers, but a greater proportion of regular workers. When considering the position of plants within the productivity distribution, we find that those at the top hire greater numbers of non-regular workers but they are also more likely to dismiss these same types of workers, when compared to plants on lower rungs of the productivity distribution. These results may suggest that more productive firms may be using certain types of non-regular workers as a flexible form of labour and a cost buffer in the event of a macroeconomic (or structural) shock. Finally, the analysis finds that establishments which experienced job dismissals in the past, substitute away from regular to non-regular workers in the present.

While this paper provides some interesting insights regarding the nature of employee composition and what is driving this change, future work is need. Further analyses on the underlying reasons explaining the differences in the regional distribution of non-regular and haken workers could provide important policy insights. Also, linking plants to firms within the Census of Manufacturers would allow to more fully understand how employees are being reallocated across plants within a firm overtime. Assessing the determinants of these changes, identifying the types of employees that are being reallocated and understanding where they are being reallocated to, would also be particularly insightful to policy makers, helping them to design effective policies to facilitate structural adjustment and productivity growth, while at the same time mitigating social costs. 


\section{Endnotes}

${ }^{1}$ The ability of firms to grow during expansionary periods and shrink/exit during downturns is also important for aggregate productivity growth (Restuccia and Rogerson, 2013[38]).

${ }^{2}$ In this paper, employee composition refers to the share of non-regular to regular employees.

${ }^{3}$ Temporary workers are another type of workers in Japan, whose contract is lasts for less than one month. However, it is not possible to disentangle whether these are haken or part time workers. See Chapter 2. for details on contract types.

${ }^{4}$ Of course this would depend on the gap between regular and non-regular workers within a particular area.

${ }^{5}$ This report is a follow-up to (Silva et al., 2019[5]), focusing predominantly on the economic effects of structural adjustment for manufacturing firms in Japan.

${ }^{6}$ Concentrated dismissals are defined here as a considerable (10\%) net employment reduction taking place in an establishment during within a year a reduction.

${ }^{7}$ Note that the total number of "non-regular" workers reported in this paper may differ from statistics using the de jure definition of non-regular workers. The Census of Manufacturing defines non-regular workers by their title in workplace, while the de jure definition of non-regular workers depends on contract lengths. See Kambayashi (2017[7]) for an in-depth discussion of employment type definitions in Japan.

${ }^{8}$ It should be noted that the Haken variable used in the analysis described in this paper includes both the number of "haken" workers and that of "transferred workers". "Transferred workers" are employees who are temporary transferred from their assignor companies to affiliated companies. Generally, transferred workers tend to carry out higher skilled tasks than "haken" workers.

${ }^{9}$ Note that only $0.07 \%$ of plants in the sample employ temporary workers.

${ }^{10}$ A part-time worker typically works between 5 and 8 hours a day. However on rare occasions they may work longer hours but tend not to receive the same types of benefits that full-time workers do.

${ }^{11}$ See Table A.1 in the annex

${ }^{12}$ Please refer to (Ministry of Health, 2019[40]) which provides more detailed explain on policy changes around employment contracts.

${ }^{13}$ This refers to the difference between the revenue of the haken company and the salary of haken workers

${ }^{14}$ See Frey and Osborne (2017[18]) on the types of tasks robots and automation may most likely undertake.

${ }^{15}$ From a service robot perspective, Eggleston et al $\left(202 \mathrm{O}_{[45]}\right)$ provides a recent examination on the effects of robots in Japanese nursing homes.

${ }^{16}$ In is important to note that the productivity effects on employment may be twofold: under allocative efficiency, productivity may have a positive impact on employment and the size of the firm however in the short run, productivity may have a negative effect on labor requirements.

${ }^{17}$ The number of regular workers with low- and high-wage jobs remained broadly unchanged.

${ }^{18}$ The official name of dataset in Japanese is 工業統計調査 (Kougyou Toukei Chousa).

${ }^{19}$ Note that this dataset does not contain information for the year 2011.

${ }^{20}$ Offshoring refers to the share of imported intermediates (less energy) over total intermediate inputs (Feenstra and Hanson, 1996[41]).

${ }^{21}$ Industrial robots are defined by ISO 8373:2012: "a machine that embodies the following characteristics: can be reprogrammed, is multipurpose in function, allows for physical alteration, and is mounted on an axis."

22 The dataset used in this paper excludes plants with less than 30 employees since the Census of Manufacturers does not include regular and detail information (on the variables used in this paper) for these plants.

${ }^{23}$ Note that non-regular workers refer to any employee who is not on a regular full-time contract. The variable in this paper is constructed as the sum of part-time and haken workers within a plant.

${ }^{24}$ Out of the firms that experienced a concentrated dismissal, only $10 \%$ of the plants witnessed employment declines greater than $25 \%$ over the same period.

${ }^{25}$ Descriptives for other geographies in Japan are available upon request.

${ }^{26}$ Non-regular employees refer to the sum of part-time and haken workers. 
${ }^{27}$ TFP is calculated with Levinsohn and Petrin (2003[42]). These estimates also control for hours worked, by relying on sector-level information obtained from RIETI JIP Database and the Monthly Labour Survey conducted by the Ministry of Health, Labour and Welfare.

${ }^{28}$ Offshore measure is the share of imported intermediate inputs (less energy) over today demanded inputs (less energy) (Feenstra and Hanson, $\left.1996_{[41]}\right)$.

${ }^{29}$ Robot stock is estimated similarly to De Backer et al $\left(2018_{[43]}\right)$ and Graetz and Michaels $\left(2018_{[44]}\right)$ using PIM and assuming a 10\% annual depreciation.

${ }^{30}$ Not surprising, plant output also consistently predicts greater numbers of all employee types including non-regular, part-time and haken workers (See Table A.3 in the Appendix).

${ }^{31}$ Out of possible concerns for endogeneity bias the results are re-run taking lagged TFP both for time t-1 and t-2 (see Table A.5 in the annex). The results are consistent with what is found in Table 5.

${ }^{32}$ Note that the results in Table 5 are also robust to the inclusion of measures of regular and non-regular worker wages (See Table A.3 in Appendix).

${ }^{33}$ It is not possible to identify skilled and unskilled employee in each employment types with the Census of Manufacturers dataset.

${ }^{34}$ The results are robust to the exclusion of plants connected to multi-plant firms.

${ }^{35}$ Note that this result does not rule out the possible presence of reverse causality where TFP may be higher in firms that use more of a certain type of worker.

${ }^{36}$ This concentrated dismissal definition is consistent with the classification used in Silva et al (2019[5]).The results presented below are consistent with the use of different layoff thresholds (including plant employment declines by $5 \%, 15 \%$ and/or $20 \%$.

${ }^{37}$ While not the scope of this paper, it is important to note that it is difficult to identify plant closure in the dataset, because unique plant identifiers change if a plant either moves or changes sectors.

${ }^{38}$ All employees coefficients calculated as $(-0.029+0.004+0.006+0.009=-0.010)$ and regular workers coefficient as $(-0.038+0.003+0.005+0.008=-0.022)$.

${ }^{39}$ Robustness tests using shorter lags ( $\mathrm{t}-1$ and $\mathrm{t}-2$ ) find consistent results (see Table A.5 in Appendix) to the baseline estimates.

${ }^{40}$ These additional results are excluded for brevity.

${ }^{41}$ The effects of concentrated dismissals in time $t-1, t-2, t-3$ and $t-4$ are consistent with what is found for $t-$ 5 and are excluded for brevity.

${ }^{42}$ This does not however mean that the effect between haken and other non-regular workers is statistically different. 


\section{References}

Acemoglu, D. and P. Restrepo (2017), Robots and Jobs: Evidence from US Labor Markets,

National Bureau of Economic Research, Cambridge, MA, http://dx.doi.org/10.3386/w23285.

Ahn, S., K. Fukao and K. Ito (2008), "Outsourcing in East Asia and its impact on the Japanese and Korean Labour Markets”, OECD Trade Policy Working Paper 65, https://www.oecdilibrary.org/trade/outsourcing-in-east-asia-and-its-impact-on-the-japanese-and-koreanlabour-markets 244366638573 .

Asano, H., T. Ito and D. Kawaguchi (2013), "Why has the fraction of nonstandard workers increased? A case study of Japan”, Scottish Journal of Political Economy, Vol. 6o/4, pp. 360-389, http://dx.doi.org/10.1111/sjpe.12015.

Asao, Y. (2011), “Overview of non-regular employment in Japan”, in JILPT Report: Nonregular employment, issues and challenges common to the major developed countries, The Japan Institute for Labour Policy and Training.

Baldwin, R., L. Winters and V. Strauss-Kahn (2013), “The Role of Globalization in the WithinIndustry Shift Away from Unskilled Workers in France”, in Challenges to Globalization, http://dx.doi.org/10.7208/chicago/9780226036557.003.0007.

Baqaee, D. and E. Farhi (2020), "Productivity and Misallocation in General Equilibrium”, The Quarterly Journal of Economics, Vol. 135/1, pp. 105-163, http://dx.doi.org/10.1093/qje/qjzo30.

Bartelsman, E., J. Haltiwanger and S. Scarpetta (2013), "Cross-country differences in productivity: The role of allocation and selection”, American Economic Review, Vol. 103/1, pp. 305-334, http://dx.doi.org/10.1257/aer.103.1.305.

Berlingieri, G., S. Calligaris and C. Criscuolo (2018), “The Productivity-Wage Premium: Does Size Still Matter in a Service Economy?”, AEA Papers and Proceedings, Vol. 108, pp. 328333, http://dx.doi.org/10.1257/pandp.20181068.

Brynjolfsson, E. and A. Mcafee (2014), The Second Machine Age: Work, Progress and Prosperity in a TIme of Brilliant Technologies, W.W. Norton \& Company.

Cabinet Office (2013), Japanese Economy 2012-2013, White paper in Japanese.

[37]

Calvino, F., C. Criscuolo and C. Menon (2015), "Cross-country evidence on start-up dynamics", OECD Science, Technology and Industry Working Papers, No. 2015/6, OECD Publishing, Paris, https://dx.doi.org/10.1787/5jirxtkb9mxtb-en.

Carlsson, M., J. Messina and O. Skans (2016), "Wage Adjustment and Productivity Shocks", Economic Journal, Vol. 126/595, pp. 1739-1773, http://dx.doi.org/10.1111/ecoj.12214.

Davis, S. and J. Haltiwanger (2014), "Labor Market Fluidity and Economic Performance”, National Bureau of Economic Research Working Paper Series, Vol. No. 20479/November, p. 98, http://dx.doi.org/10.3386/w20479. 
De Backer, K. et al. (2018), "Industrial robotics and the global organisation of production", https://www.oecd-ilibrary.org/content/paper/dd98ff58-en.

Eggleston, K., T. Iizuka and Y. Lee (2020), "The impact of robots on staffing in nursing homes", Forthcoming.

Falk, M. and B. Koebel (2002), "Outsourcing, imports and labour demand”, Scandinavian Journal of Economics, Vol. 104/4, pp. 567-586, http://dx.doi.org/10.1111/14679442.00302.

Feenstra, R. and G. Hanson (1999), THE IMPACT OF OUTSOURCING AND HIGHTECHNOLOGY CAPITAL ON WAGES: ESTIMATES FOR THE UNITED STATES, 19791990*, https://academic.oup.com/qje/article-abstract/114/3/907/1848125.

Feenstra, R. and G. Hanson (1996), "Globalization, Outsourcing, and Wage Inequality", American Economic Review, Vol. 86/2, pp. 240-245.

Ford, M. (2016), Rise of the robots : technology and the threat of a jobless future, Basic Books, New York.

Frey, C. and M. Osborne (2017), "The future of employment: How susceptible are jobs to computerisation?", Technological Forecasting and Social Change, Vol. 114, pp. 254-280, http://dx.doi.org/10.1016/J.TECHFORE.2016.08.019.

Graetz, G. and G. Michaels (2018), "Robots at work", Review of Economics and Statistics, Vol. 100/5, pp. 753-768, http://dx.doi.org/10.1162/rest a 00754 .

Hijzen, A., H. Görg and R. Hine (2005), International outsourcing and the skill structure of labour demand in the United Kingdom, http://dx.doi.org/10.1111/j.14680297.2005.01022.x.

Hokkaido, U. (2009), Agriculture in Hokkaido, Laboratory of Crops Science, Research Faculty of Agriculture.

IFR (2017), World Robotics Report 2017.

Kambayashi, R. (2017), Seiki no Sekai Hiseki no Sekai, Keio University Press (in Japanese).

Kambayashi, R. and T. Kato (2017), Long-Term Employment and Job Security Over the Last Twenty-Five Years: A Comparative Study of Japan and the U.S.

Kawaguchi, D. and Y. Ueno (2013), "Declining long-term employment in Japan”, Journal of the Japanese and International Economies, Vol. 28, pp. 19-36, http://dx.doi.org/10.1016/j.jjie.2013.01.005.

Kiyota, K. and S. Maruyama (2017), "ICT, offshoring, and the demand for part-time workers: The case of Japanese manufacturing”, Journal of Asian Economics, Vol. 48, pp. 75-86, http://dx.doi.org/10.1016/j.asieco.2016.10.007.

Kojima, S. (2010), "When dismissal become a business transaction: Analysis of the processes and consequences of haken-giri under the global recession", Contemporary Japan, Vol. 22/1-2, pp. 23-45.

Levinsohn, J. and A. Petrin (2003), "Estimating Production Functions Using Inputs to Control for Unobservables", Review of Economic Studies, Vol. 70/2, pp. 317-341, 
http://dx.doi.org/10.1111/1467-937X.00246.

Lucas, R. (1978), "On the Size Distribution of Business Firms", The Bell Journal of Economics,

[35] Vol. 9/2, p. 508, http://dx.doi.org/10.2307/3003596.

Matsuura, T., H. Sato and R. Wakasugi (2011), "Temporary Workers, Permanent Workers, and International Trade: Evidence from Japanese firm-level data”, Discussion papers.

Melitz, M. (2003), "The Impact of Trade on Intra-Industry Reallocations and Aggregate Industry Productivity”, Econometrica, Vol. 71/6, pp. 1695-1725, http://dx.doi.org/10.1111/1468-0262.00467.

Ministry of Health, Labour and Welfare (2009), "Annual Health, Labour and Welfare Report 2008-2009” July 2009, pp. 28-101, https://www.mhlw.go.jp/english/wp/wphw3/index.html.

Ministry of Health, L. (2019), Revision of the part-time employment act and the worker dispatching act, Ministry of Health, Labour and Welfare, https://www.mhlw.go.jp/english/policy/employ-labour/fixed-term-workers/index.html.

OECD (2019), Trade in Value Added: Measuring recent trends in Global Value Chains $O E C D$, https://www.oecd.org/sdd/its/tiva-nowcast.htm.

OECD (2018), OECD Employment Outlook 2018, OECD (forthcoming).

OECD (2017), OECD Employment Outlook 2017, OECD Publishing, Paris, https://dx.doi.org/10.1787/empl outlook-2017-en.

OECD (2015), Structural adjustment in the steel sector: Japan's experience, http://www.oecd.org/sti/ind/Item8 JapanExperienceOnStructuralAdjustment 2015.pdf.

Restuccia, D. and R. Rogerson (2013), Misallocation and productivity, http://dx.doi.org/10.1016/j.red.2012.11.003.

Silva, F. et al. (2019), "Structural adjustment, mass lay-offs and employment reallocation", OECD Science, Technology and Industry Policy Papers, No. 72, OECD Publishing, Paris, http://dx.doi.org/10.1787/90b572f3-en.

Sugeno, K. and K. Yamakoshi (2014), "Dismissals in Japan. Part one: how strict is japanese law on employers?”, Japan labor review, Vol. 11/2, pp. 83-92.

Takahashi, K. (2012), "The Way of Working and Consciousness of Keiyaku-Shain”, Japan Labor Review, Vol. 9/3, pp. 127-151.

Tanaka, A., B. Ito and R. Wakasugi (2019), "How do exporters respond to exogenous shocks: Evidence from Japanese firm-level data", Japan and the World Economy, http://dx.doi.org/10.1016/j.japwor.2019.100962.

Yokoyama, I., K. Higa and D. Kawaguchi (2019), "Employment Adjustments of Regular and Non-Regular Workers to Exogenous Shocks: Evidence from Exchange-Rate Fluctuation", ILR Review, p. 001979391988796, http://dx.doi.org/10.1177/0019793919887961. 


\section{Annex A. Additional tables and figures}

\section{Table A.1. Worker Dispatch Law: Targeted jobs}

\begin{tabular}{|c|l|}
\hline Year & Targeted jobs \\
\hline 1985 & $\begin{array}{l}\text { software developers, business machine operators, translator and stenographers, official administrators, filing clerks, } \\
\text { research services, financial affairs, business document writers, executant or demonstrator of new products, tour } \\
\text { conductors, building cleaners, operation and inspection (maintenance) of building equipment, receptionist at } \\
\text { information desks, machine designers, broadcast machine operators, television and radio writers }\end{array}$ \\
\hline 1996 & $\begin{array}{l}\text { research and development associates, planner and designer and implementer of business systems, editor and } \\
\text { producer of books, advertising designers, interior coordinators, announcers, instructors of Office Automation (OA), } \\
\text { telemarketers, sales engineers and production (set) of equipment for broadcast programmers }\end{array}$ \\
\hline Year & Exceptions \\
\hline 1999 & port transport, construction, security, medical treatment and manufacturers of objects \\
\hline
\end{tabular}

Source: Kambayashi (2017[7]).

Table A.2. Sectoral classifications

\begin{tabular}{|c|c|}
\hline JSIC Code & Description \\
\hline 9 & "MANUFACTURE OF FOOD \\
\hline 10 & MANUFACTURE OF BEVERAGES,TOBACCO AND FEED \\
\hline 11 & MANUFACTURE OF TEXTILE PRODUCTS \\
\hline 12 & MANUFACTURE OF LUMBER AND WOOD PRODUCTS, EXCEPT FURNITURE \\
\hline 13 & MANUFACTURE OF FURNITURE AND FIXTURES \\
\hline 14 & MANUFACTURE OF PULP, PAPER AND PAPER PRODUCTS \\
\hline 15 & PRINTING AND ALLIED INDUSTRIES \\
\hline 16 & MANUFACTURE OF CHEMICAL AND ALLIED PRODUCTS \\
\hline 17 & MANUFACTURE OF PETROLEUM AND COAL PRODUCTS \\
\hline 18 & MANUFACTURE OF PLASTIC PRODUCTS, EXCEPT OTHERWISE CLASSIFIED \\
\hline 19 & MANUFACTURE OF RUBBER PRODUCTS \\
\hline 20 & MANUFACTURE OF LEATHER TANNING, LEATHER PRODUCTS AND FUR SKINS \\
\hline 21 & MANUFACTURE OF CERAMIC, STONE AND CLAY PRODUCTS \\
\hline 22 & MANUFACTURE OF IRON AND STEEL \\
\hline 23 & MANUFACTURE OF NON-FERROUS METALS AND PRODUCTS \\
\hline 24 & MANUFACTURE OF FABRICATED METAL PRODUCTS \\
\hline 25 & MANUFACTURE OF GENERAL-PURPOSE MACHINERY \\
\hline 26 & MANUFACTURE OF PRODUCTION MACHINERY \\
\hline 27 & MANUFACTURE OF BUSINESS ORIENTED MACHINERY \\
\hline 28 & ELECTRONIC PARTS, DEVICES AND ELECTRONIC CIRCUITS \\
\hline 29 & MANUFACTURE OF ELECTRICAL MACHINERY, EQUIPMENT AND SUPPLIES \\
\hline 30 & MANUFACTURE OF INFORMATION AND COMMUNICATION ELECTRONICS EQUIPMENT \\
\hline 31 & MANUFACTURE OF TRANSPORTATION EQUIPMENT \\
\hline 32 & MISCELLANEOUS MANUFACTURING INDUSTRIES \\
\hline
\end{tabular}

Note: Sector classifications are 2-digit Japanese Standard Industrial Classification. 
40 | STRUCTURAL ADJUSTMENT AND CHANGES TO EMPLOYMENT USE IN JAPAN

Figure A.1. Share of employee types by 2-digit sector, 2001

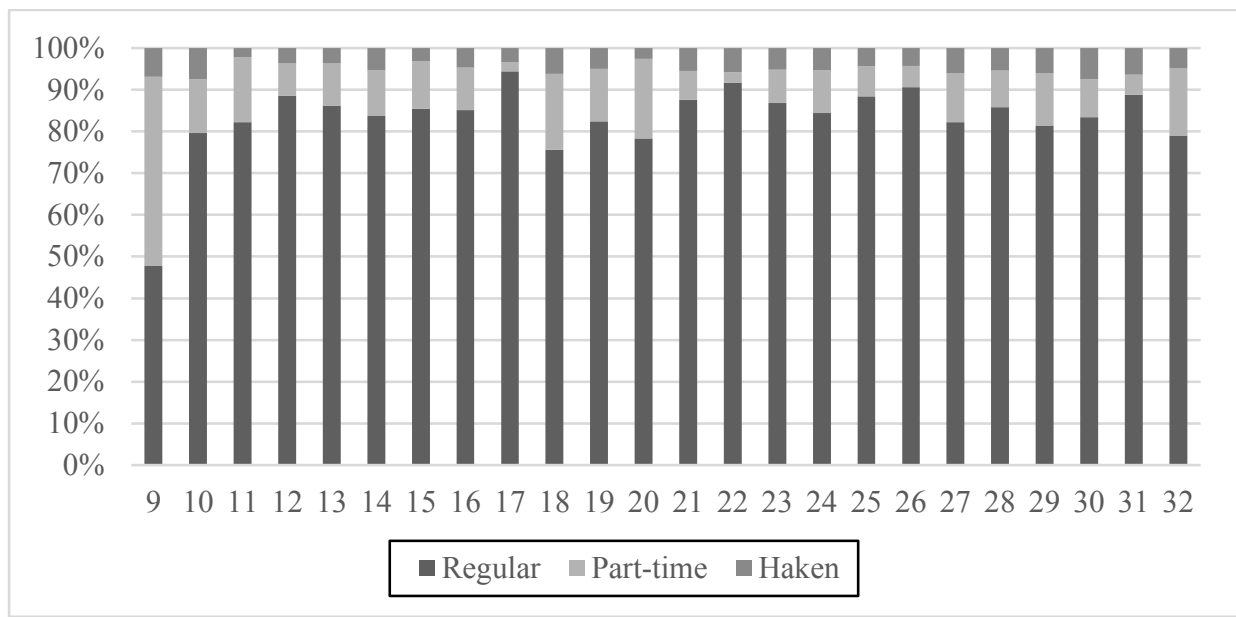

Note: The following figure illustrates the share of employee type by 2-digit sector for the year 2001. Sector classifications are the Japanese Standard Industrial Classification.

Source: Census of Manufacturers, calculations by authors. 
STRUCTURAL ADJUSTMENT AND CHANGES TO EMPLOYMENT USE IN JAPAN

Table A.3. Determinants of Employee Use, controlling for output and wages

\begin{tabular}{|c|c|c|c|c|c|c|c|c|c|c|}
\hline $\begin{array}{l}\text { Dependent } \\
\text { variable }\end{array}$ & Composition & Composition & Regular & Regular & Non-Reg & Non-Reg & Part-time & Part-time & Haken & Haken \\
\hline \multirow[t]{2}{*}{ Output } & $-0.013^{* *}$ & & $0.305^{* * *}$ & & $0.321^{* *}$ & & $0.186^{* *}$ & & $0.314^{* * *}$ & \\
\hline & (o.0o) & & (o.oo) & & (o.oo) & & (o.oo) & & (o.oo) & \\
\hline \multirow[t]{2}{*}{ TFP } & & $-0.053^{* *}$ & & $0.244^{* *}$ & & $0.156^{* *}$ & & $0.093^{* * *}$ & & $0.146^{* * *}$ \\
\hline & & (o.oo) & & (o.0o) & & (0.00) & & (o.0o) & & (0.00) \\
\hline \multirow[t]{2}{*}{ Multi-plant } & -0.000 & 0.000 & $0.006^{* * *}$ & o.oo9 & 0.005 & o.011+ & 0.003 & 0.006 & 0.004 & 0.009 \\
\hline & (o.oo) & (o.oo) & (o.0o) & (o.oo) & (o.oo) & (o.oo) & (o.oo) & (o.oo) & (o.oo) & (o.oo) \\
\hline \multirow[t]{2}{*}{ Offshoring } & $-0.015^{* *}$ & -0.009 & $0.060^{* * *}$ & $0.082^{* * *}$ & O.039* & $0.080^{* * *}$ & $0.123^{* * *}$ & $0.146^{* *}$ & $0.105^{* *}$ & $0.147^{* * *}$ \\
\hline & (o.0o) & (o.oo) & (o.0o) & (o.oo) & (o.01) & (o.01) & (o.02) & (o.02) & (0.03) & (o.03) \\
\hline \multirow[t]{2}{*}{ Robot stock } & $-0.018^{* *}$ & $-0.017^{* *}$ & $0.044^{* * *}$ & $0.048^{* *}$ & $-0.026^{* *}$ & $-0.018^{*}$ & -0.010 & -0.005 & $-0.048^{* *}$ & $-0.040^{* * *}$ \\
\hline & (o.0o) & (o.0o) & (o.0o) & (o.0o) & (o.0o) & (o.oo) & (0.01) & (o.01) & (0.01) & (0.01) \\
\hline \multirow[t]{2}{*}{ Wages Reg } & $0.396^{* * *}$ & $0.404^{* * *}$ & $-0.462^{* * *}$ & $-0.45^{* *}$ & $0.408^{* *}$ & $0.440^{* * *}$ & $0.608^{* *}$ & $0.626^{* * *}$ & $0.118^{* *}$ & $0.151^{* * *}$ \\
\hline & (o.0o) & (o.oo) & (0.00) & (o.oo) & (o.oo) & (o.0o) & (o.0o) & (o.oo) & (0.01) & (0.01) \\
\hline \multirow[t]{2}{*}{ Wages Non reg } & $-0.015^{* *}$ & $-0.014^{* *}$ & -0.000 & $-0.001^{* * *}$ & $-0.130^{* *}$ & $-0.129^{* *}$ & $-0.131^{* * *}$ & $-0.130^{* *}$ & $0.011^{* * *}$ & o.012 \\
\hline & (0.00) & (o.0o) & (0.00) & (o.0o) & (o.0o) & (0.00) & (o.0o) & (0.00) & (0.00) & (0.00) \\
\hline \multirow{2}{*}{\multicolumn{11}{|c|}{ Fixed effects }} \\
\hline & & & & & & & & & & \\
\hline Plant & $\checkmark$ & $\checkmark$ & $\checkmark$ & $\checkmark$ & $\checkmark$ & $\checkmark$ & $\checkmark$ & $\checkmark$ & $\checkmark$ & $\checkmark$ \\
\hline Year & $\checkmark$ & $\checkmark$ & $\checkmark$ & $\checkmark$ & $\checkmark$ & $\checkmark$ & $\checkmark$ & $\checkmark$ & $\checkmark$ & $\checkmark$ \\
\hline 4 digit sector & $\checkmark$ & $\checkmark$ & $\checkmark$ & $\checkmark$ & $\checkmark$ & $\checkmark$ & $\checkmark$ & $\checkmark$ & $\checkmark$ & $\checkmark$ \\
\hline Region & $\checkmark$ & $\checkmark$ & $\checkmark$ & $\checkmark$ & $\checkmark$ & $\checkmark$ & $\checkmark$ & $\checkmark$ & $\checkmark$ & $\checkmark$ \\
\hline Observations & 305480 & 305480 & 305480 & 305480 & 305480 & 305480 & 305480 & 305480 & 305480 & 305480 \\
\hline R-squared & 0.912 & 0.913 & 0.964 & 0.960 & 0.851 & 0.846 & 0.850 & 0.849 & 0.726 & 0.723 \\
\hline
\end{tabular}

Note: Composition refers to the share or non-regular to regular workers. Regular, non-regular, part-time and haken represent the number of employee types by plant Fixed effects included in each model listed in the table. Regressions are clustered at the plant-year level with robust standard errors in parenthesis. Level of significance are $* * * 1 \%, * * 5 \%, * 10 \%$ 
42 I STRUCTURAL ADJUSTMENT AND CHANGES TO EMPLOYMENT USE IN JAPAN

Table A.4. Determinants of Employee Use, lagged TFP

\begin{tabular}{|c|c|c|c|c|c|c|c|c|c|c|}
\hline $\begin{array}{l}\text { Dependent } \\
\text { variable }\end{array}$ & Composition & Composition & Regular & Regular & Non-Reg & Non-Reg & Part-time & Part-time & Haken & Haken \\
\hline \multirow[t]{2}{*}{ TFP, t-1 } & $-0.021^{* * *}$ & & $0.173^{* * *}$ & & $0.091^{* * *}$ & & $0.064^{* * *}$ & & $0.086^{* * *}$ & \\
\hline & (0.00) & & (0.0o) & & $(0.00)$ & & $(0.00)$ & & $(0.00)$ & \\
\hline \multirow[t]{2}{*}{ TFP, t-2 } & & $-0.024^{* * *}$ & & $0.137^{* * * *}$ & & $0.035^{* * *}$ & & $0.029^{* * * *}$ & & $0.030^{* * * *}$ \\
\hline & & $(0.00)$ & & $(0.00)$ & & $(0.00)$ & & $(0.00)$ & & $(0.00)$ \\
\hline \multirow[t]{2}{*}{ Multi-plant } & 0.001 & 0.000 & $0.010^{* * *}$ & $0.011^{* * *}$ & $0.012^{*}$ & $0.015^{* * *}$ & 0.002 & 0.009 & 0.008 & 0.014 \\
\hline & $(0.00)$ & $(0.00)$ & $(0.00)$ & $(0.00)$ & $(0.00)$ & $(0.00)$ & $(0.00)$ & $(0.00)$ & $(0.00)$ & $(0.00)$ \\
\hline \multirow[t]{2}{*}{ Offshoring } & $-0.013^{*}$ & -0.009 & $0.089^{* * * *}$ & $0.054^{* * * *}$ & $0.097^{* * * *}$ & $0.062^{* * * *}$ & $0.138^{* * *}$ & $0.108^{* * *}$ & $0.136^{* * *}$ & $0.091^{* * *}$ \\
\hline & (0.00) & (0.00) & (0.01) & $(0.00)$ & (0.02) & (0.02) & (0.01) & (0.01) & (0.03) & $(0.02)$ \\
\hline \multirow[t]{2}{*}{ Robot stock } & $-0.019^{* * * *}$ & $-0.018^{* * * *}$ & $0.042^{* * *}$ & $0.036^{* * *}$ & $-0.055^{* * *}$ & $-0.050^{* * *}$ & $-0.058^{* * *}$ & $-0.040^{* * *}$ & 0.003 & $-0.014^{*}$ \\
\hline & (0.00) & (0.00) & (0.00) & $(0.00)$ & $(0.00)$ & $(0.00)$ & $(0.00)$ & $(0.00)$ & $(0.00)$ & (0.00) \\
\hline \multicolumn{11}{|l|}{ Fixed effects } \\
\hline Plant & $\checkmark$ & $\checkmark$ & $\checkmark$ & $\checkmark$ & $\checkmark$ & $\checkmark$ & $\checkmark$ & $\checkmark$ & $\checkmark$ & $\checkmark$ \\
\hline Year & $\checkmark$ & $\checkmark$ & $\checkmark$ & $\checkmark$ & $\checkmark$ & $\checkmark$ & $\checkmark$ & $\checkmark$ & $\checkmark$ & $\checkmark$ \\
\hline 4 digit sector & $\checkmark$ & $\checkmark$ & $\checkmark$ & $\checkmark$ & $\checkmark$ & $\checkmark$ & $\checkmark$ & $\checkmark$ & $\checkmark$ & $\checkmark$ \\
\hline Region & $\checkmark$ & $\checkmark$ & $\checkmark$ & $\checkmark$ & $\checkmark$ & $\checkmark$ & $\checkmark$ & $\checkmark$ & $\checkmark$ & $\checkmark$ \\
\hline $\mathrm{R}$-squared & 0.903 & 0.910 & 0.944 & 0.949 & 0.828 & 0.835 & 0.845 & 0.852 & 0.721 & 0.729 \\
\hline Observations & 388883 & 333867 & 389679 & 334467 & 389679 & 334467 & 389679 & 334467 & 389679 & 334467 \\
\hline
\end{tabular}

Note: Composition refers to the share or non-regular to regular workers. Regular, non-regular, part-time and haken represent the number of employee types by plant. Fixed effects included in each model listed in the table. Regressions are clustered at the plant-year level with robust standard errors in parenthesis. Level of significance are $* * * 1 \%, * * 5 \%, * 10 \%$. 
Table A.5. Effects of concentrated dismissals ( $t-1, t-2, t-3, t-4, t-5)$ on present employee composition

\begin{tabular}{|c|c|c|}
\hline Dependent variable & Composition & Composition \\
\hline \multirow{2}{*}{ Conc. dismissals, t-1 } & & $0.002 *$ \\
\hline & & $(0.00)$ \\
\hline \multirow[t]{2}{*}{ Conc. dismissals, $\mathrm{t}-2$} & & $0.013 * *$ \\
\hline & & $(0.00)$ \\
\hline \multirow[t]{2}{*}{ Conc. dismissals, $\mathrm{t}-3$} & $0.009 * *$ & $0.019^{* *}$ \\
\hline & $(0.00)$ & $(0.00)$ \\
\hline \multirow[t]{2}{*}{ Conc. dismissals, $\mathrm{t}-4$} & $0.011 * *$ & $0.018 * *$ \\
\hline & $(0.00)$ & $(0.00)$ \\
\hline \multirow[t]{2}{*}{ Conc. dismissals, $\mathrm{t}-5$} & $0.012 * *$ & $0.014 * *$ \\
\hline & $(0.00)$ & $(0.00)$ \\
\hline \multirow[t]{2}{*}{ TFP } & 0.000 & 0.003 \\
\hline & $(0.00)$ & $(0.00)$ \\
\hline \multirow[t]{2}{*}{ Multi-plant } & 0.001 & -0.001 \\
\hline & $(0.00)$ & $(0.003)$ \\
\hline \multirow[t]{2}{*}{ Offshoring } & -0.000 & $0.023 * *$ \\
\hline & $(0.00)$ & $(0.00)$ \\
\hline \multirow[t]{2}{*}{ Robot stock } & $-0.033 * *$ & $-0.082 * *$ \\
\hline & $(0.00)$ & $(0.01)$ \\
\hline \multicolumn{3}{|l|}{ Fixed effects } \\
\hline Plant & $\checkmark$ & $\checkmark$ \\
\hline Year & $\checkmark$ & $\checkmark$ \\
\hline 4 digit industry & $\checkmark$ & $\checkmark$ \\
\hline Region & $\checkmark$ & $\checkmark$ \\
\hline Observations & 196,056 & 125,118 \\
\hline R-squared & 0.928 & 0.942 \\
\hline
\end{tabular}

Note: Composition refers to the share or non-regular to regular workers. Concentrated dismissal refers to a reduction of total employment of the plant of $10 \%$ or more in year $\mathrm{t}-1, \mathrm{t}-2, \mathrm{t}-3, \mathrm{t}-4$ and $\mathrm{t}-5$. Fixed effects included in each model are stated in the table. Regressions are clustered at the plant-year level with robust standard errors in parenthesis. Level of significance are $* * * 1 \%, * * 5 \%, * 10 \%$. 